\title{
SynGAP Regulates ERK/MAPK Signaling, Synaptic Plasticity, and Learning in the Complex with Postsynaptic Density 95 and NMDA Receptor
}

\author{
Noboru H. Komiyama, ${ }^{1}$ Ayako M. Watabe, ${ }^{2}$ Holly J. Carlisle, ${ }^{3}$ Karen Porter, ${ }^{1}$ Paul Charlesworth, ${ }^{1}$ \\ Jennifer Monti, ${ }^{1}$ Douglas J. C. Strathdee, ${ }^{1}$ Colin M. O'Carroll,, ${ }^{1}$ Stephen J. Martin, ${ }^{1}$ Richard G. M. Morris, ${ }^{1}$ \\ Thomas J. O'Dell, ${ }^{2}$ and Seth G. N. Grant ${ }^{1}$ \\ ${ }^{1}$ Division of Neuroscience, University of Edinburgh, Edinburgh EH8-9JZ, United Kingdom, and 2Department of Physiology \\ and ${ }^{3}$ Interdepartmental PhD Program for Neuroscience, University of California Los Angeles School of Medicine, Los \\ Angeles, California 90095
}

At excitatory synapses, the postsynaptic scaffolding protein postsynaptic density 95 (PSD-95) couples NMDA receptors (NMDARs) to the Ras GTPase-activating protein SynGAP. The close association of SynGAP and NMDARs suggests that SynGAP may have an important role in NMDAR-dependent activation of Ras signaling pathways, such as the MAP kinase pathway, and in synaptic plasticity. To explore this issue, we examined long-term potentiation (LTP), p42 MAPK (ERK2) signaling, and spatial learning in mice with a heterozygous null mutation of the SynGAP gene $\left(\right.$ SynGAP $\left.^{-/+}\right)$. In SynGAP ${ }^{-/+}$ mutant mice, the induction of LTP in the hippocampal CA1 region was strongly reduced in the absence of any detectable alteration in basal synaptic transmission and NMDAR-mediated synaptic currents. Although basal levels of activated ERK2 were elevated in hippocampal extracts from SynGAP ${ }^{-/+}$mice,

At many excitatory synapses, activation of postsynaptic NMDAtype glutamate receptors by different patterns of synaptic activity can induce persistent increases and decreases in the strength of synaptic transmission. Within the postsynaptic density, NMDA receptors (NMDARs) exist as multiprotein complexes (NRC, NMDA receptor complex) that contain neurotransmitter receptors and cell adhesion proteins linked by adaptors to signaling and cytoskeletal proteins (Husi et al., 2000). The colocalization of multiple signaling pathways into a complex with NMDA receptors might have several important implications for NMDA receptor signaling (Migaud et al., 1998). For instance, the presence of general signaling proteins, such as ERK or protein kinase A (PKA), in these complexes might allow NMDA receptor activation to regulate the function of these proteins within a spatially restricted postsynaptic microdomain (Westphal et al., 1999; Hardingham et al., 2001). In addition, these multicomponent signaling complexes might also allow intracomplex signal interactions that

Received June 25, 2002; revised Aug. 9, 2002; accepted Aug. 14, 2002.

This work was supported by the Wellcome Trust (S.G.N.G., K.P., J.M., N.H.K., P.C.), European Community (N.H.K.), Gatsby Charitable Foundation (D.S.), Medical Research Council (R.G.M., S.J.M., C.O.), Pew Charitable Trusts (T.J.O.), and grants from the National Institute of Mental Health (T.J.O.). We thank C. Ingham for Golgi staining and EM; J. Young, J. Robinson, and J. O'Connell for mouse care and technical assistance; and S. Nada for DT-A vector.

Correspondence should be addressed to Dr. Seth Grant, Division of Neuroscience, 1 George Square, University of Edinburgh, EH8 9JZ, UK. E-mail: seth.grant@ed.ac.uk.

Copyright $@ 2002$ Society for Neuroscience $0270-6474 / 02 / 229721-12 \$ 15.00 / 0$
NMDAR stimulation still induced a robust increase in ERK activation in slices from SynGAP ${ }^{-1+}$ mice. Thus, although SynGAP may regulate the ERK pathway, its role in LTP most likely involves additional downstream targets. Consistent with this, the amount of potentiation induced by stimulation protocols that induce an ERK-independent form of LTP were also significantly reduced in slices from SynGAP ${ }^{-/+}$mice. An elevation of basal phospho-ERK2 levels and LTP deficits were also observed in SynGAP ${ }^{-1+} / \mathrm{H}_{-}$Ras $^{-1-}$ double mutants, suggesting that SynGAP may normally regulate Ras isoforms other than H-Ras. A comparison of SynGAP and PSD-95 mutants suggests that PSD-95 couples NMDARs to multiple downstream signaling pathways with very different roles in LTP and learning.

Key words: SynGAP; H-Ras; PSD-95; long-term potentiation; hippocampus; spatial learning enable activation of distinct downstream pathways in response to different patterns of neuronal activity. Properties of this type could have a crucial role in NMDAR-dependent forms of synaptic plasticity, learning, and developmental plasticity, which are dependent on many of the proteins found within these complexes (Husi et al., 2000; Erzurumlu and Kind, 2001).

One key component of NRCs is postsynaptic density 95 (PSD95), an NMDA receptor-associated protein that may function as an adapter protein that couples various signaling molecules to NMDA receptors (Kornau et al., 1995; Blackstone and Sheng, 1999; Garner et al., 2000). Although the phenotype of PSD-95 mutant mice indicates an important role for this protein in both synaptic plasticity and learning (Migaud et al., 1998), the relevant PSD-95-dependent signaling pathways involved in these processes have not yet been identified. One recently identified candidate, however, is SynGAP, a protein that colocalizes with NMDA receptors at excitatory synapses via direct interactions with the PDZ domains of PSD-95 (Chen et al., 1998; Kim et al., 1998). Both the structure and in vitro enzyme activity of SynGAP indicate that it is a likely GTPase-activating protein for H-Ras. SynGAP may thus be an important component of signaling pathways that underlie NMDA receptor-dependent activation of Rasdependent signaling pathways such as the c-Raf1-MEK-ERK, PI3-kinase, and RalA pathways (Gille and Downward, 1999).

To investigate the role of SynGAP in synaptic plasticity and learning, we have begun a genetic dissection of the NRC using mice with single and compound mutations in SynGAP, H-Ras, 
and PSD-95. Our results indicate that SynGAP has an important role in both learning and long-term potentiation (LTP) in the hippocampal CA1 region. Although PSD-95 couples SynGAP to NMDA receptors (Chen et al., 1998; Kim et al., 1998), we found that PSD-95 and SynGAP mutant mice exhibit distinct physiological and behavioral phenotypes, suggesting that PSD-95 may couple NMDA receptors to multiple downstream signaling pathways with very different roles in LTP and learning.

\section{MATERIALS AND METHODS}

Gene targeting. An internal ribosomal entry site upstream of a $\beta$-galactosidase reporter gene was introduced to monitor the cellular expression pattern (Migaud et al., 1998). Targeting constructs were electroporated into embryonic stem (ES) cells, and Southern blot analysis indicated that homologous recombination had occurred in 18 of 180 clones (10\%) for SynGAP and 58 of $72(81 \%)$ for H-Ras and germline transmission of the mutations established (see Fig. $1 a, b$ ). A 565 bp cDNA fragment that encodes part of the SynGAP pleckstrin homology and C2 domains was generated from mouse brain RNA extract by RT-PCR. This cDNA was used as a probe to screen a 129/Ola mouse genomic library, and overlapping $\lambda$ clones covering $22 \mathrm{~kb}$ of the SynGAP locus were isolated. To construct a SynGAP targeting vector, an $8.1 \mathrm{~kb} S m a \mathrm{I}-X h o \mathrm{I}$ fragment and a $3.8 \mathrm{~kb}$ SpeI-SpeI fragment were used as $5^{\prime}$ and $3^{\prime}$ homology arms, respectively. A coding sequence for hemagglutinin (HA) epitope tag was inserted in frame at an XhoI site in the C2 domain (Chen et al., 1998; Kim et al., 1998) at the $3^{\prime}$ end of the $5^{\prime}$ homology arm and followed by stop codons and internal ribosomal entry site (IRES)-lacZpolyA - MC1neo-polyA cassette (Friedrich and Soriano, 1991). The resultant vector deletes exons encoding the $\mathrm{C} 2$ and GAP domains. The Diphtheria toxin A gene (MC1-DT-A) was used as a negative selection marker. The targeting vector was linearized and electroporated into E14TG2a ES cells. Neomycin (neo)-resistant clones were screened for homologous recombination by Southern blot analysis using a $700 \mathrm{bp} \mathrm{3}$ flanking probe (EcoRI or XbaI digest) and a 354 bp cDNA internal 5' probe (BglII digest). The targeting vector for the H-Ras1 locus comprised 1.9 and $5.5 \mathrm{~kb}$ bands of $5^{\prime}$ and $3^{\prime}$ DNA flanking a cassette (TAG3-IRESBgeo-polyA) containing the positive selectable marker neo. The $5^{\prime}$ end of this cassette contained stop codons in all reading frames to terminate translation of H-Ras at the SpeI site in exon 4, followed by an IRES that allows a $\beta$-geo reporter gene to be expressed under the control of the $\mathrm{H}$-Ras1 promoter. The targeting construct was linearized and electroporated into HM1 ES cells. Neomycin-resistant clones were screened for homologous recombination by Southern blot analysis using a $1.1 \mathrm{~kb}$ fragment $\left(5^{\prime}\right.$ probe) flanking the homology region and a $1.2 \mathrm{~kb}$ genomic DNA (3' probe). Chimeric mice were produced by injecting targeted ES cells into C57BL/6 blastocysts, and heterozygous mutants were generated as described previously (Papaioannou and Johnson, 2000). All comparisons of SynGAP ${ }^{-/+}$and wild-type (wt) mice were performed using littermates on an F2 MF1 genetic background. Animals were treated in accordance with the UK Animal Scientific Procedures Act (1986) and National Institutes of Health guidelines.

Biochemistry. The hippocampus was homogenized in $50 \mathrm{~mm}$ Tris- $\mathrm{HCl}$, $1 \%$ sodium deoxycholate, $50 \mathrm{~mm} \mathrm{NaF}, 20 \mathrm{~mm} \mathrm{ZnCl}_{2}, 1 \mathrm{~mm}$ sodium orthovanadate, $0.5 \mathrm{mg} / \mathrm{ml} \mathrm{PMSF}$, and Protease Inhibitors Complete (Roche Molecular Biochemicals). Proteins were separated by SDSPAGE ( $25 \mu \mathrm{g}$ per lane), and standard procedures were used for Western blotting. The antibodies used were SynGAP, NR2A (Upstate Biotechnology); Neurofibromin-1 (NF1), SynGAP, HA (Santa Cruz Biotechnology); p120RasGAP, H-Ras, NR1, NR2B, PSD-95, ERK, MEK (Transduction Laboratories); panRas (Oncogene); phospho-MAPK (pERK) and phospho-MEK (New England BioLabs).

Morphology. Mice were perfusion fixed via the heart with heparinized saline followed by $2 \%$ paraformaldehyde, $2.5 \%$ glutaraldehyde in $0.1 \mathrm{M}$ sodium phosphate buffer, $\mathrm{pH}$ 7.4. The brain was removed and placed in fixative for a further $2 \mathrm{hr}$. Coronal sections $(70 \mu \mathrm{m})$ were taken through the anterior part of the hippocampus using a vibrating microtome (Vibratome, Lancer). From every three serial sections, one was taken for EM processing and the remainder were used for section Golgi impregnation. Sections were dehydrated and mounted in resin before viewing in the light microscope. Consistent regions of dorsal CA1 were resectioned and viewed in an electron microscope (Philips CM12) (Bolam, 1992; Morrison et al., 1998). The stratum radiatum was examined, and the first 20 clearly defined asymmetrical axospinous synapses were photographed.
5-Bromo-4-chloro-3-indolyl- $\beta$-galactoside staining. SynGAP mice were fixed via cardiac perfusion with 0.1 M sodium phosphate buffer, $\mathrm{pH} 7.4$, followed by $4 \%$ paraformaldehyde in $0.1 \mathrm{~m}$ sodium phosphate buffer, $\mathrm{pH}$ 7.4. The brain was removed and placed in fixative for a further $1 \mathrm{hr}$. Frozen sagittal sections were cut at $48 \mu \mathrm{m}$ and then stained overnight for 5-bromo-4-chloro-3-indolyl- $\beta$-galactoside (X-gal; Invitrogen) (Migaud et al., 1998). H-Ras unfixed sagittal sections were cut at $20 \mu \mathrm{m}$ and then fixed using $0.01 \%$ glutaraldehyde in $0.1 \mathrm{M}$ sodium phosphate buffer, $\mathrm{pH}$ 7.4, for $15 \mathrm{~min}$ and then stained overnight for X-gal (Invitrogen) (Migaud et al., 1998). Sections were dehydrated and mounted in PDX mountant $(\mathrm{BDH})$ before viewing in the light microscope.

Immunofluorescent staining. Brain tissue was fixed in $10 \%$ buffered Formalin for $6 \mathrm{hr}$, dehydrated, and then wax embedded. Coronal sections $(8 \mu \mathrm{m})$ were cut on a microtome. Standard procedures were followed for immunofluorescent staining, mounting, and coverslipping (Morrison et al., 1998). Primary antibodies were anti-synaptophysin monoclonal antibody (mAb) (1:100; Boehringer Mannheim) and MAP2B mAb (1:100; Transduction Labs); secondary antibody was Cy3-conjugated antibody (1:200; Jackson Laboratory, Bar Harbor, ME).

Slice electrophysiology. Hippocampal slices (400 $\mu \mathrm{m}$ thick) were prepared from 14- to 20-week-old mice using standard techniques and maintained in interface-type recording chambers perfused at a constant rate $(1-3 \mathrm{ml} / \mathrm{min})$ with a warmed $\left(30^{\circ} \mathrm{C}\right)$, oxygenated $\left(95 \% \mathrm{O}_{2} / 5 \% \mathrm{CO}_{2}\right)$ artificial CSF (ACSF) consisting of (in $\mathrm{mm}$ ): $124 \mathrm{NaCl}, 4.4 \mathrm{KCl}, 25$ $\mathrm{Na}_{2} \mathrm{HCO}_{3}, 1 \mathrm{NaH}_{2} \mathrm{PO}_{4}, 1.2 \mathrm{MgSO}_{4}, 2 \mathrm{CaCl}_{2}$, and 10 glucose. Lowresistance glass microelectrodes filled with ACSF were placed into stratum radiatum of the hippocampal CA1 region to record field EPSPs (fEPSPs) evoked by presynaptic stimulation pulses delivered once every $50 \mathrm{sec}$ to the Schaffer collateral/commissural fibers via a bipolar nichrome wire stimulating electrode. At the beginning of each experiment the intensity of presynaptic fiber stimulation was adjusted to evoke fEPSPs that were approximately half of the maximal fEPSP amplitude that could be evoked by strong intensity stimulation. High-frequency stimulation-induced LTP was elicited using two trains of $100 \mathrm{~Hz}$ stimulation (1 sec in duration) delivered with an intertrain interval of $10 \mathrm{sec}$. To elicit saturating levels of LTP, we delivered six, 1-sec-long trains of $100 \mathrm{~Hz}$ stimulation with an intertrain interval of $5 \mathrm{~min}$. For statistical comparisons (unpaired $t$ tests, two-tailed; $n=$ number of animals), we compared the average amount of potentiation present 55-60 min after the first high-frequency stimulation train or 40-45 min after lowfrequency trains of stimulation.

Whole-cell current-clamp recordings were used to study the induction of LTP by low-frequency presynaptic fiber stimulation paired with postsynaptic depolarization. In these experiments, slices with the CA3 region removed were bathed in a modified ACSF containing elevated levels of $\mathrm{CaCl}_{2}$ and $\mathrm{MgSO}_{4}$ (4 mM each), lower levels of $\mathrm{KCl}(2.2 \mathrm{mM})$, and $100 \mu \mathrm{M}$ picrotoxin. EPSPs evoked by $0.05 \mathrm{~Hz}$ presynaptic fiber stimulation were recorded from individual CA1 pyramidal cells using low-resistance (2-5 M $\Omega$ ) patch-clamp electrodes filled with a solution containing (in mM): 122.5 Cs-gluconate, $17.5 \mathrm{CsCl}, 10 \mathrm{TEA}-\mathrm{Cl}, 0.2$ EGTA, 10 HEPES, 2 Mg-ATP, and 0.3 GTP, pH 7.2. Constant current injections were used to hyperpolarize cells to between -80 and $-85 \mathrm{mV}$, and a 50-msec-long $0.1 \mathrm{nA}$ pulse of hyperpolarizing current was injected $150 \mathrm{msec}$ after each evoked EPSP to monitor input and access resistance throughout the experiment. The intensity of presynaptic fiber stimulation was set to evoke EPSPs between 5 and $10 \mathrm{mV}$ in amplitude. After a 10 min period of baseline recording, LTP was induced by depolarizing the postsynaptic cell to near $0 \mathrm{mV}$ using a tonic injection of current through the recording electrode and pairing this depolarization with 100 presynaptic fiber stimulation pulses delivered at $5 \mathrm{~Hz}$. Membrane potential was closely monitored during the pairing protocol, and the amount of current injected through the recording electrode was adjusted continuously to keep the postsynaptic membrane potential near $0 \mathrm{mV}$. Unpaired $t$ tests (two-tailed) were used to compare the average amount of LTP induced 25-30 min after pairing in cells from wild-type and mutant animals. Whole-cell voltage-clamp recordings were used to examine the NMDA receptor-mediated component of EPSCs across a range of postsynaptic membrane potentials. In these experiments, slices were bathed in the modified ACSF described above, and CA1 pyramidal cells were voltage clamped using patch-clamp electrodes (2-4 M ; access resistance ranged from 14 to $22 \mathrm{M} \Omega$ ) filled with either the Cs-gluconate-based electrode-filling solution or with a solution containing (in $\mathrm{mM}$ ): 120 $\mathrm{CsMeSO}_{3}, 20 \mathrm{CsCl}, 8 \mathrm{NaCl}, 0.2 \mathrm{EGTA}, 10 \mathrm{HEPES}, 4 \mathrm{Mg}$-ATP, and 0.3 GTP, $\mathrm{pH}$ 7.2. Similar results were obtained with both internal solutions, and the results were combined. The AMPA and NMDA receptor- 
mediated components of the EPSCs were estimated from the amplitude of the EPSCs measured 5 and $50 \mathrm{msec}$, respectively, after the onset of the EPSC. All experiments and initial data analysis were performed blind except for experiments performed on three $\mathrm{H}-\mathrm{Ras}^{-1-}$ mutant mice. The results from these experiments did not differ from additional experiments on these animals that were done in a blind manner, and the results were therefore combined. All values are reported as mean \pm SEM.

Primary neuronal culture and electrophysiology. Standard techniques were used to prepare primary cultures of forebrain neurons from individual embryonic day 18 (E18) mice that were subsequently genotyped. Briefly, forebrain was dissected, transferred to cold PBS, trypsinized, and disaggregated by drawing up and down in a $1 \mathrm{ml}$ pipette or flamed Pasteur pipette. The resultant cell suspension was centrifuged twice, and the pellet was resuspended in Neurobasal medium supplemented with B27 (Invitrogen) and $0.5 \mathrm{~mm}$ glutamine. Cells were plated at $\sim 0.5-1 \times$ $10^{5} / \mathrm{cm}^{2}$ on glass coverslips coated with poly-D-lysine and laminin (Sigma, St. Louis, MO). NMDA receptor-mediated responses were examined in wild-type, SynGAP ${ }^{-/+}$, and SynGAP ${ }^{-/-}$neurons maintained in culture for 6-9 d. Before an experiment, cells were bathed in an external solution that contained $140 \mathrm{~mm} \mathrm{NaCl}, 3 \mathrm{mM} \mathrm{KCl}, 2.5 \mathrm{mM} \mathrm{CaCl}_{2}, 0$ or 1 $\mathrm{mM} \mathrm{MgCl}_{2}, 10 \mathrm{~mm}$ glucose, $20 \mathrm{nM}$ TTX, and $15 \mathrm{~mm}$ HEPES, pH 7.4. Whole-cell voltage-clamp recordings were performed using lowresistance electrodes filled with a solution containing (in $\mathrm{mM}$ ): 120 $\mathrm{CsMeSO}_{3}$, 5 CsBAPTA, 4 MgATP, $0.4 \mathrm{Na}_{2} \mathrm{GTP}$, and $15 \mathrm{HEPES}, \mathrm{pH}$ 7.3. Currents were evoked by brief application of $100 \mu \mathrm{M}$ NMDA $(+10$ $\mu \mathrm{M}$ glycine) delivered by a solenoid valve-operated U-tube perfusion system. Responses were recorded and analyzed using PClamp software (Axon Instruments). For each cell, NMDA-evoked currents were elicited at different holding potentials and then normalized to the maximal current response. These values were then averaged across all cells recorded from a given genotype.

Slice stimulation. Hippocampal slices were prepared and maintained in the same interface chambers as those used for electrophysiological experiments and were allowed to recover for at least $2 \mathrm{hr}$. Slices (six at a time) were either left untreated (control slices) or exposed to $100 \mu \mathrm{M}$ NMDA ( $10 \mu \mathrm{M}$ glycine) for $2.5,5$, or $10 \mathrm{~min}$. The slices were removed rapidly from the chamber and immediately frozen in liquid $\mathrm{N}_{2}$. Samples were homogenized in the same buffer as described above for Western blot analyses. Three separate experiments were performed with tissue obtained from six wild-type and six SynGAP ${ }^{-1+}$ mice.

Behavior. We used an open-field water maze (2 $\mathrm{m}$ in diameter; opaque water; $25 \pm 1^{\circ} \mathrm{C}$; automated swim path monitoring). In the cue task, mice were trained to a randomly located platform position marked with a cylindrical cue [four trials per day for $3 \mathrm{~d} ; 30 \mathrm{~cm}$ platform diameter; curtains drawn around the pool to occlude extra-maze cues; maximum trial duration was $90 \mathrm{sec}$; intertrial interval (ITI), $10 \mathrm{~min}$ ]. For spatial training, we used a hidden platform with the extra maze cues visible (four trials per day for $5 \mathrm{~d}$; $30 \mathrm{~cm}$ platform diameter; platform/pool area was $1: 44 ; 30 \mathrm{sec}$ was spent on the platform at the end of each trial; maximum trial duration $90 \mathrm{sec}$; ITI, $10 \mathrm{~min}$ ). Transfer test 1 was conducted $10 \mathrm{~min}$ after the previous training trial, and mice were placed in the pool for $60 \mathrm{sec}$ (platform absent; the start position was opposite to whatever training quadrant had been used for each individual animal). Two measures of transfer test performance were calculated: (1) percentage time spent in the target quadrant of the pool and (2) time spent in a zone corresponding to the area of the absent platform (radius $=15 \mathrm{~cm}$ ), expressed as a percentage of the total time spent in all four possible zones (see Fig. 8d,f). Training to criterion involved using a smaller hidden platform, $(20 \mathrm{~cm}$ diameter; platform area/pool area ratio was 1:100), again with the extra maze cues visible, until the animals had completed 2 consecutive days with each trial taking $<20 \mathrm{sec}$, or until 32 trials had been completed. On reaching criterion, and $10 \mathrm{~min}$ after the previous training trial, individual mice were placed in the pool for $60 \mathrm{sec}$ (platform absent; transfer test 2). This training protocol was identical to that used for PSD-95 $-1-$ mice (Migaud et al., 1998), thus enabling a comparison of the performance of PSD-95 $-1-$ and SynGAP ${ }^{-1+}$ mutant mice. Two replications completed testing up to this point (SynGAP ${ }^{-1+}$ total, $n=21$; wild type total, $n=21$ ). Only the initial replication underwent retention testing as follows (SynGAP ${ }^{-/+}, n=12$; wild type, $n=12)$. Two further transfer tests, or retention tests, were conducted 7 and $45 \mathrm{~d}$ after the mice had reached criterion and had completed the second transfer test. Again, mice were placed in the pool for $60 \mathrm{sec}$ (platform absent; transfer test 3 and 4, respectively).

\section{RESULTS}

The murine genes encoding SynGAP and H-Ras were cloned and characterized, knock-out targeting vectors were constructed (Fig. $1 a, b)$, and mutant mice were generated. Male and female Syn$\mathrm{GAP}^{-/+}$mice appeared normal, displayed no sign of seizures, tremor, ataxia, or other neurological abnormality, and were fertile. Genotypes of 3-week-old pups from SynGAP ${ }^{-1+}$ intercrosses showed no surviving homozygote SynGAP ${ }^{-1-}$ animals. Of 543 pups born, 325 reached weaning, of which 128 were wild type and 197 SynGAP $^{-1+}\left(\chi^{2}=8.417 ; p<0.001\right)$. Eighty newborn pups were genotyped and showed normal mendelian transmission of the mutation (23 wt, 39 SynGAP $^{-1+}$, 18 Syn$\left.\mathrm{GAP}^{-/-} ; \chi^{2}=0.714 ; p>0.05\right)$. All SynGAP ${ }^{-/-}$pups were observed to breathe and feed and showed no gross anatomical abnormality, although most died within $48 \mathrm{hr}$, indicating that SynGAP is essential for postnatal viability. In contrast, H-Ras ${ }^{-1+}$ intercrosses produced H-Ras ${ }^{-1-}$ offspring at the expected mendelian ratio (323 pups at weaning, $93 \mathrm{wt}, 152{\mathrm{H}-\mathrm{Ras}^{-1+}}^{-19}$ H-Ras $\left.{ }^{-1-} ; \chi^{2}=0.293 ; p>0.05\right)$. These offspring were fertile and showed no signs of neurological abnormality.

The neuronal expression pattern of SynGAP is unknown, and $\mathrm{X}$-gal staining of SynGAP ${ }^{-1+}$ brains revealed highest expression in neurons of the hippocampus CA1 and dentate gyrus and cortex and lower expression in striatum (Fig. 1c), where PSD-95 is also expressed (Migaud et al., 1998). In contrast to SynGAP, H-Ras was widely expressed in most brain regions (Fig. 1c). Disruption of protein expression was confirmed using immunoblotting of hippocampal extracts (Fig. 1d). SynGAP levels were reduced by $50 \%$ in SynGAP ${ }^{-/+}$compared with wild-type mice $(p<0.001$; $n=12$ ) using both $\mathrm{N}$ - and C-terminal antibodies. No truncated protein products were detected using these antibodies or with antibodies to the HA tag inserted into the locus. Immunoblotting of H-Ras showed no detectable H-Ras in hippocampus extracts from H-Ras ${ }^{-1-}$ mice. We tested for compensation by the two other mammalian GAP proteins, NF1 and p120RasGAP, in the hippocampus extracts of SynGAP ${ }^{-1+}$ mice and observed no increases above wild-type levels (Fig. 1d). We used a Pan-Ras antibody that detects all Ras isoforms and saw a reduction in total Ras levels in H-Ras mutant mice. Finally, we examined levels of expression of NR1, NR2A, NR2B, and PSD-95 in SynGAP ${ }^{-/+}$ and H-Ras ${ }^{-1-}$ mutant mice and saw no changes from wild-type levels (Fig. 1d).

To explore the role of SynGAP and H-Ras in the brain, we examined the neuroanatomy at the light and electron microscopic level in mature (6-8 weeks old) SynGAP ${ }^{-/+}$and $\mathrm{H}-\mathrm{Ras}^{-/-}$ mice (Fig. 2). There was no gross detectable abnormality found using Nissl staining in the brain of SynGAP ${ }^{-/+}$or $\mathrm{H}_{-\mathrm{Ras}^{-/-}}$ mice. Both SynGAP and H-Ras were highly expressed in the CA1 region of the hippocampus (Fig. 1c). In this region, the intensity and distribution of Nissl staining and the distribution of the synaptic-terminal marker synaptophysin and of the dendritic marker MAP2 were the same in SynGAP ${ }^{-/+}, \mathrm{H}_{-} \mathrm{Ras}^{-/-}$, and wild-type mice (Fig. 2). Dendritic architecture was further examined using Golgi staining and electron microscopy, revealing dendritic branching, spine distribution, and asymmetric synapse morphology, which were all normal. We prepared primary neuronal cultures from individual E18.5 embryos and found that neurons from SynGAP ${ }^{-1-}$ mice extended neurites and formed morphological synapses, as shown by immunostaining with the synaptic vesicle proteins synaptophysin and dendritic protein MAP2, which were indistinguishable from wild-type cultures. 
a

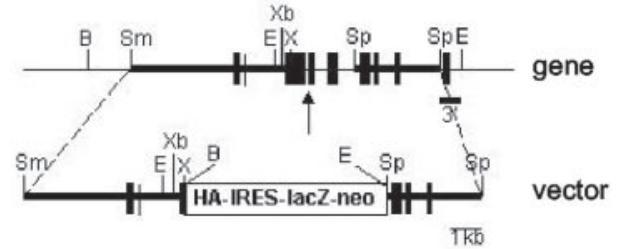

b

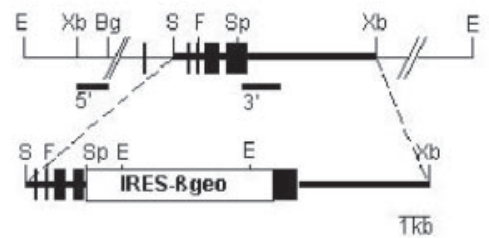

gene

vector

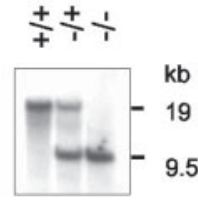

C SynGAP
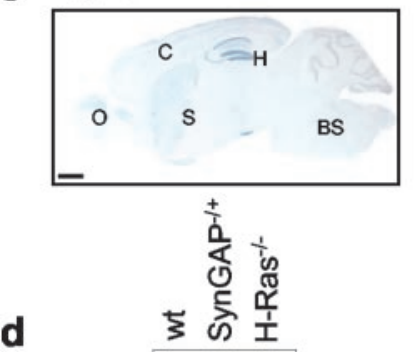

SynGAP $=-$

NF-1

H-Ras

RasGAP

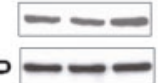

Pan-Ras

H-Ras
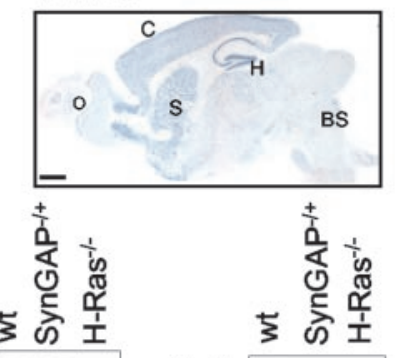

变离

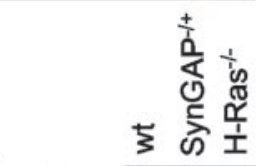

Nera
NR2B

PSD-95

Figure 1. SynGAP and H-Ras mutant mice. $a$, Targeted disruption of SynGAP gene. Top, SynGAP gene with restriction enzyme sites $(B, B g l \mathrm{II}$; E, Eco RI; Sm, SmaI; Sp, SpeI; X, XhoI; Xb, XbaI); black boxes, exon; thick horizontal lines, homologous regions used in the targeting vector; Southern blot probes are indicated $\left(3^{\prime}\right)$. Bottom, SynGAP targeting vector. $H A$, Hemagglutinin sequence; IRES, internal ribosomal entry site; lac $\mathrm{Z}$, $\beta$-galactosidase gene; neo, neomycin-resistance gene. The arrow below the SynGAP gene indicates arginine 312 (or 470) (Chen et al., 1998; Kim et al., 1998), which is highly conserved in RasGAP proteins and necessary for GAP activity and was deleted in the targeting vector. Right, Genomic Southern blots of $E c o$ R1-digested DNA from littermates of a heterozygote intercross and probed with the $3^{\prime}$ probe. Wild type $(+/+)$, heterozygote $(-/+)$, homozygote $(-/-)$ are indicated. $b$, Targeted disruption of H-Ras gene. Top, H-Ras gene with restriction enzyme sites (abbreviations as above with the addition of the following: $B g, B g l \mathrm{I} ; S, S p h \mathbf{I} ; F, F s p \mathrm{I}$ ); all other detail as in $a$. Bottom, Targeting vector. $\beta$-geo consists of a $\beta$-galactosidase gene and a neomycin-resistance fusion gene. Right, Genomic Southern blots of EcoR1-digested DNA from littermates of a heterozygote intercross and probed with the $5^{\prime}$ probe. Wild type $(+/+)$, heterozygote $(-/+)$, homozygote $(-/-)$ are indicated. $c$, Expression patterns of SynGAP and $\mathrm{H}$-Ras using X-gal staining of whole-mount sagittal brain sections. $B S$, Brain stem; $C$, cortex; $C B$, cerebellum, $H$, hippocampus. Representative SynGAP $^{-1+}$ and H-Ras ${ }^{-/-}$sections are shown. Scale bar, $1 \mathrm{~mm} . d$, Immunoblots comparing different protein levels of wild-type mice, Syn$\mathrm{GAP}^{-1+}$, and H-Ras ${ }^{-1-}$ mutants in hippocampus extracts. Left panels, Immunoblot analysis of GAP proteins. SynGAP, NF-1, and Ras-GAP were detected in wild-type (wt), SynGAP ${ }^{-1+}$, and $\mathrm{H}-\mathrm{Ras}^{-1-}$ extracts. A reduced amount of SynGAP protein was observed in SynGAP ${ }^{-/+}$mutants compared with wild type. Middle panels, Immunoblot analysis of Ras proteins. H-Ras was detected in wild-type mice and was normal in Syn$\mathrm{GAP}^{-1+}$ mutants. Pan-Ras antibodies, which recognize all Ras isoforms, revealed lower total Ras levels in H-Ras ${ }^{-1-}$ mutants and normal levels in SynGAP ${ }^{-/+}$mutants. Right panels, Immunoblot analysis of NMDAR subunits $(N R 1, N R 2 A, N R 2 B)$ and PSD-95. Equivalent levels were observed in wild type (wt), SynGAP ${ }^{-1+}$, and H-Ras ${ }^{-1-}$ extracts.

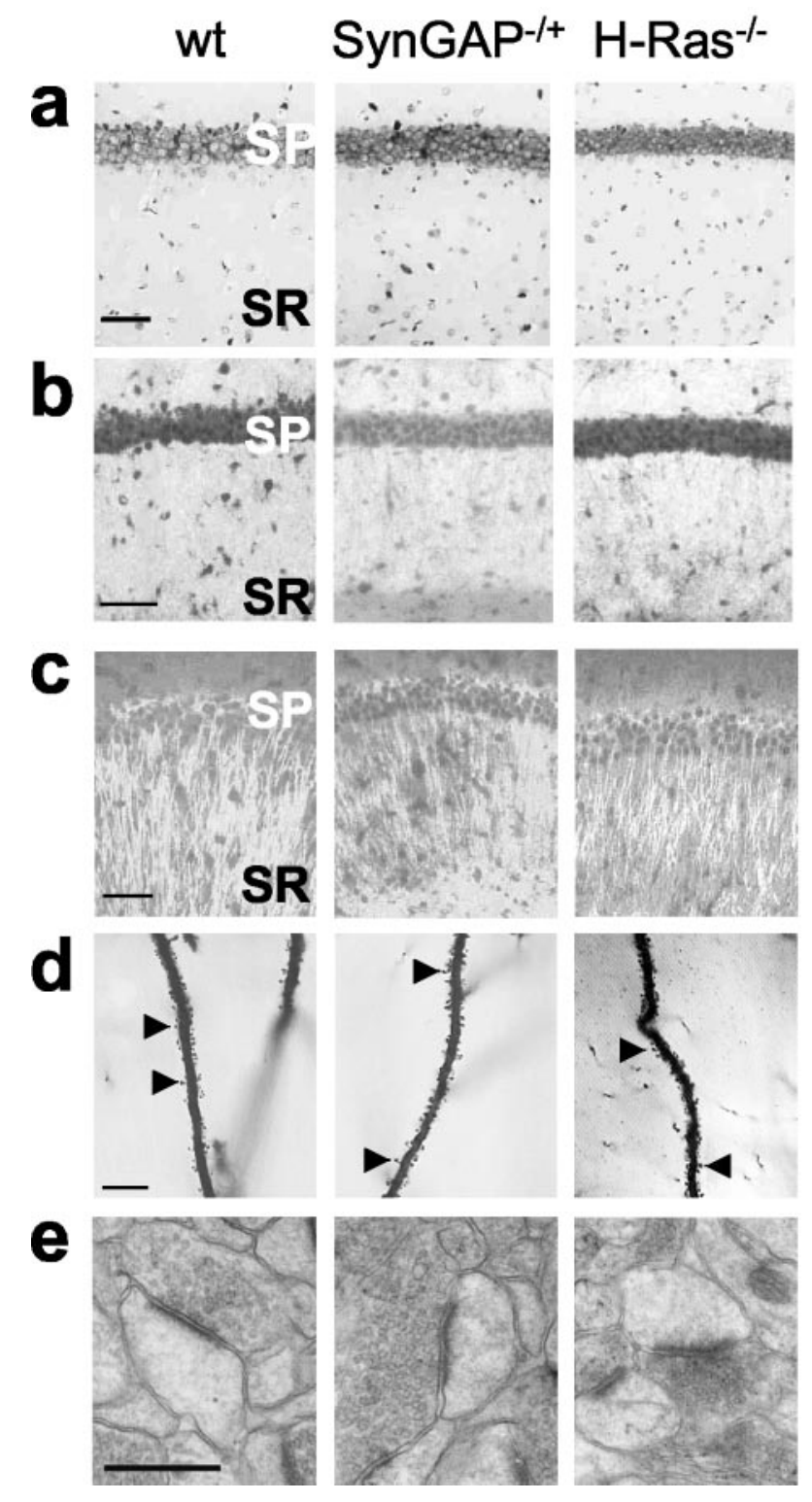

Figure 2. Neuroanatomy of hippocampus CA1 region in SynGAP ${ }^{-1+}$ and $\mathrm{H}^{-R_{a s}}{ }^{-/-}$mutant mice. $a$, Nissl; cresyl violet stain of CA1 pyramidal cells. $b$, Synaptophysin; immunohistochemistry for synaptic vesicle marker protein. $c$, MAP2; immunohistochemistry for dendritic marker protein. $d$, Golgi; montaged images of CA1 apical dendrites from Golgiimpregnated pyramidal neurons in the distal region of the stratum radiatum. $e$, EM; electron micrograph images of asymmetric axospinous synapses in the stratum radiatum of the CA1 region. Scale bars: $a-c, 50 \mu \mathrm{m}$; $d, 10 \mu \mathrm{m} ; e, 0.5 \mu \mathrm{m}$. $S R$, Stratum radiatum; $S P$, pyramidal cell body layer; $w t$, wild type. SynGAP$P^{-1+}$ and $H-R a s^{-1-}$ mutants are indicated.

Electrophysiological evidence for synaptic transmission between SynGAP ${ }^{-1-}$ neurons was obtained using whole-cell patch clamping to record miniature EPSCs and showed typical kinetics of glutamatergic responses (data not shown). These data indicate that SynGAP was not essential for synapse formation or synaptic transmission in vitro.

\section{Synaptic transmission and NMDA receptor function in SynGAP mutant mice}

We next examined the role of SynGAP in synaptic transmission and plasticity in the CA1 region of the hippocampus. Under normal experimental conditions, where extracellularly recorded 

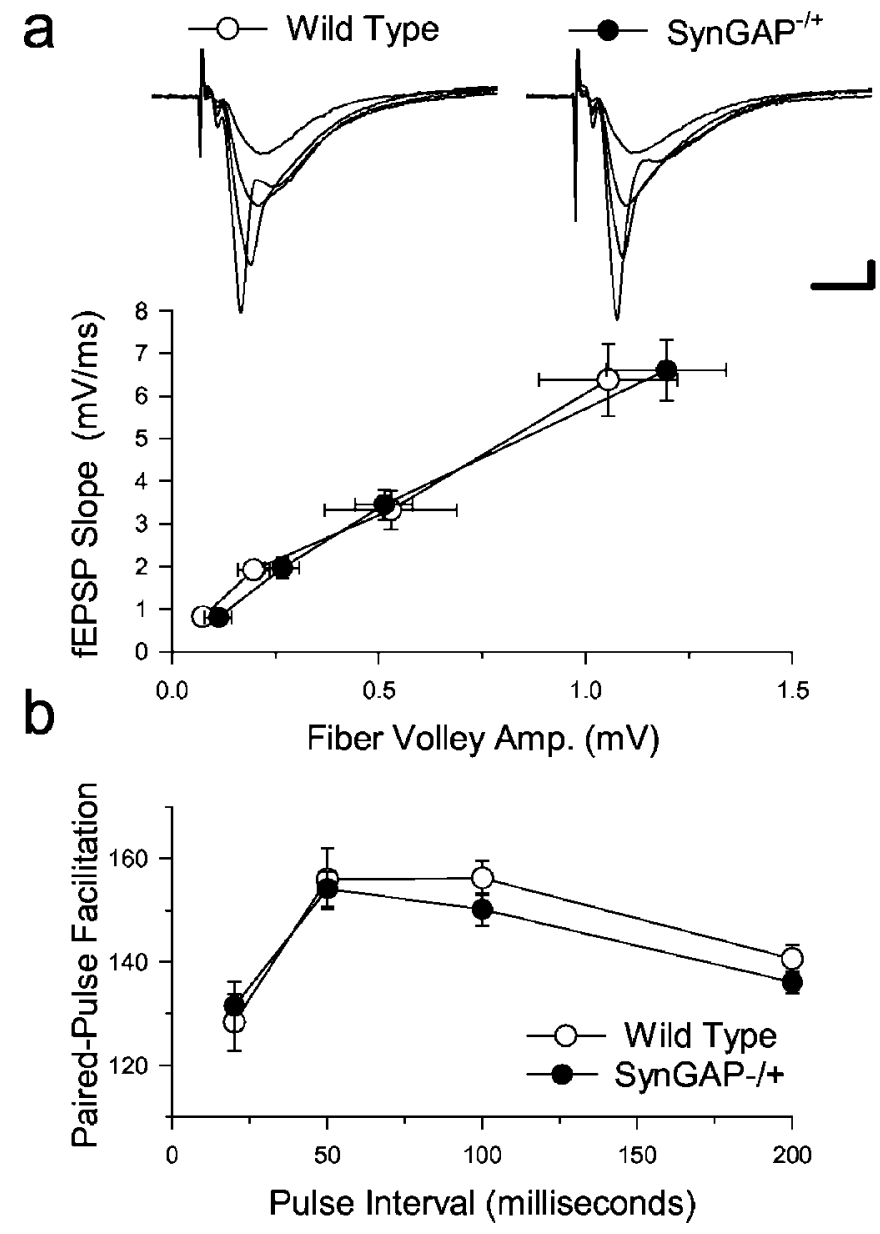

Figure 3. Basal properties of synaptic transmission are unaltered in SynGAP mutant mice. $a$, Input-output curves were generated by comparing the fiber volley amplitude and slope of fEPSPs elicited by presynaptic stimulation intensities that evoked fEPSPs that were $25,50,75$, and $100 \%$ of the maximal fEPSP amplitude that could be generated in each slice. No differences across all four stimulation intensities were evident in slices from SynGAP ${ }^{-1+}(\bullet, n=18$ slices from 5 animals $)$ and wild-type $(\bigcirc, n=19$ slices from 5 animals) mice. Inset shows overlaid traces (each an average of 3 responses) evoked in a slice from a wild-type (left set of traces) and SynGAP ${ }^{-1+}$ mutant (right set of traces) mouse. Calibration: 5 $\mathrm{msec}, 1 \mathrm{mV}$. $b$, Pairs of presynaptic stimulation pulses delivered with an interpulse interval of $25,50,100$, or $200 \mathrm{msec}$ elicits similar amounts of paired-pulse facilitation in slices from $\operatorname{SynGAP}^{-/+}(\bullet, n=16$ slices from 5 mice) and wild-type mice $(\bigcirc, n=16$ slices from 5 mice $)$.

fEPSPs are mediated predominantly by AMPA-type glutamate receptors, we detected no difference in the maximal fEPSP amplitude that could be recorded using strong intensity presynaptic fiber stimulation (maximum fEPSPs were $8.4 \pm 0.7 \mathrm{mV}$ in wildtype slices and $8.3 \pm 0.5 \mathrm{mV}$ in slices from SynGAP ${ }^{-1+}$ mice; $n=$ 23 animals for each). Moreover, the ratio of fiber volley amplitude to fEPSP slope of responses evoked using presynaptic fiber stimulation intensities that evoked fEPSPs that were 25, 50, 75, and $100 \%$ of the maximal amplitude were similar in slices from SynGAP ${ }^{-1+}$ and wild-type mice (Fig. $3 a$ ). This indicates that the number of presynaptic fibers needed to evoke an equivalent postsynaptic response in slices from wild-type and SynGAP ${ }^{-/+}$ mice was similar and suggests that the activity of postsynaptic AMPA receptors (AMPARs) is unaltered in SynGAP ${ }^{-1+}$ mice. Finally, pairs of presynaptic fiber stimulation pulses delivered at interpulse intervals of $25,50,100$, and $200 \mathrm{msec}$ evoked nearly identical amounts of paired-pulse facilitation in slices from wildtype and SynGAP ${ }^{-/+}$mice (Fig. $3 b$ ).

To examine whether the NMDAR components of EPSCs were altered in CA1 pyramidal cells in SynGAP ${ }^{-/+}$slices, we used whole-cell voltage-clamp techniques to record EPSCs at membrane potentials of -80 and $+40 \mathrm{mV}$ and compared the contribution of NMDARs to EPSCs in SynGAP ${ }^{-/+}$and wild-type cells by measuring the NMDAR currents relative to the size of the AMPAR currents recorded at holding potentials of -80 and +40 $\mathrm{mV}$. As shown in Figure $4 a$, the contribution of NMDARs to the synaptic current measured in this way was unaltered in SynGAP $^{-/+}$cells (Fig. $4 a$ ). At holding potentials of $+40 \mathrm{mV}$, where the NMDAR-mediated component of EPSCs is most evident, the absolute current mediated by both AMPA and NMDA receptors was also the same in cells from wild-type and SynGAP ${ }^{-/+}$mice (in wild-type cells the AMPAR component was $104 \pm 8 \mathrm{pA}$ and the NMDA component was $79 \pm 13 \mathrm{pA}$ in 16 cells from five animals, whereas the AMPAR and NMDAR components of EPSCs were $101 \pm 4$ and $75 \pm 5 \mathrm{pA}$, respectively, in 15 cells from five SynGAP ${ }^{-/+}$mice). Single exponential fits to the decay of the synaptic currents measured at $+40 \mathrm{mV}$ were nearly identical in cells from wild-type and SynGAP ${ }^{-1+}$ mice $\left(\tau_{\text {decay }}=58.9 \pm 6.5\right.$ msec in wild-type cells, $n=16$ cells from five animals; and $56.3 \pm$ $6 \mathrm{msec}$ in SynGAP ${ }^{-/+}$cells, $n=15$ cells from five animals), suggesting that the time course of the NMDAR-mediated component of EPSCs is not altered in SynGAP ${ }^{-/+}$cells. Finally, we also found no difference between wild-type and SynGAP ${ }^{-/+}$ neurons in both the amplitude and voltage dependence of NMDAR-mediated responses in whole-cell voltage-clamp recordings from cultured forebrain neurons (Fig. 4b,c). NMDARmediated responses were also unaltered in cultures obtained from SynGAP ${ }^{-1-}$ mice (Fig. $4 b, c$ ). Thus, we found no evidence for changes in several aspects of normal synaptic physiology, including NMDAR channel function, in SynGAP ${ }^{-/+}$mice.

\section{Synaptic plasticity in SynGAP mutant mice}

To examine whether NMDAR-dependent forms of synaptic plasticity might be altered in SynGAP ${ }^{-/+}$mice, we first investigated the effects of brief trains of high-frequency synaptic stimulation on synaptic strength at Schaffer collateral/commissural fibers synapses onto pyramidal cells in the hippocampal CA1 region. As shown in Figure $5 a, 60$ min after two, 1-sec-long trains of $100 \mathrm{~Hz}$ stimulation, synaptic transmission was potentiated $>80 \%$ in slices from wild-type mice $(n=7)$ but only $50 \%$ in slices from Syn$\mathrm{GAP}^{-/+}$mice $(n=7 ; p<0.01$ compared with wild type). The amount of LTP induced by high-frequency stimulation was also significantly reduced $(p<0.005)$ in slices from SynGAP ${ }^{-1+}$ mice in experiments in which six trains of high-frequency stimulation were delivered once every $5 \mathrm{~min}$ to induce saturating levels of LTP (Fig. 5b). Thus, although high-frequency synaptic stimulation induces significant potentiation in slices from SynGAP ${ }^{-1+}$ mice, the amount of potentiation induced by $100 \mathrm{~Hz}$ stimulation is greatly reduced compared with that seen in wild-type slices.

To explore further the diminished magnitude of LTP in Syn$\mathrm{GAP}^{-/+}$mutant slices, we examined the ability of lowerfrequency trains of synaptic stimulation to induce persistent changes in synaptic strength (Fig. 5c). A 900 pulse train of $1 \mathrm{~Hz}$ stimulation that was below threshold for LTP induction in slices from wild-type mice (fEPSPs were $98 \pm 3 \%$ of baseline $45 \mathrm{~min}$ after $1 \mathrm{~Hz}$ stimulation; $n=5$ ) also had little lasting effect on synaptic strength in slices from SynGAP ${ }^{-/+}$mice (fEPSPs were $94 \pm 3 \%$ of baseline; $n=9$ ). Likewise, 900 pulses of synaptic 

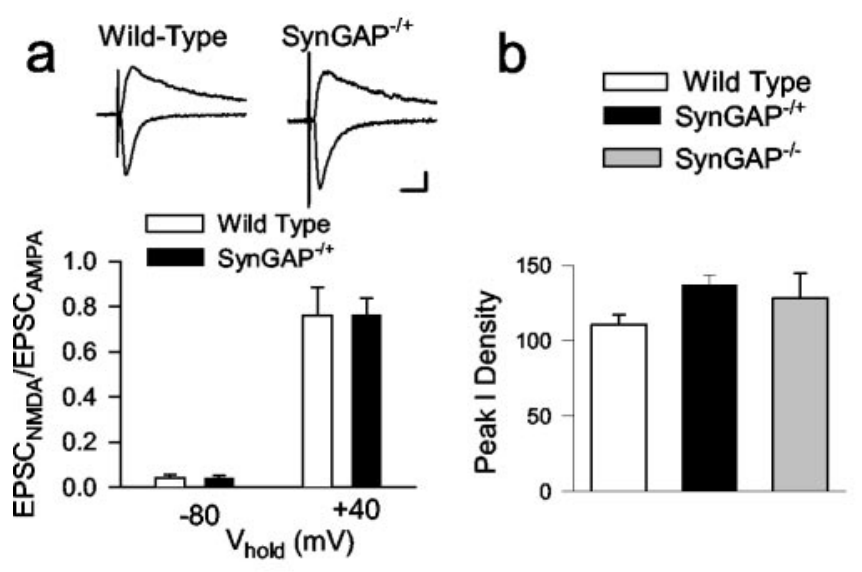

C
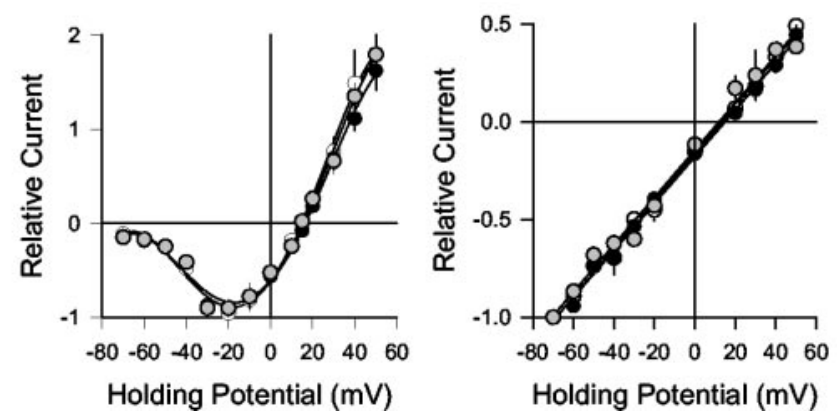

Figure 4. NMDAR-mediated currents are unaltered in SynGAP mutant mice. $a$, The magnitude of the NMDA receptor-mediated component of EPSCs was estimated by the amplitude of the synaptic currents measured $50 \mathrm{msec}$ after the start of the EPSC and expressed relative to the size of the AMPA receptor component estimated by the size of the EPSC measured $5 \mathrm{msec}$ after the start of the EPSC. The size of the NMDA receptor-mediated component of the EPSCs in pyramidal cells from SynGAP ${ }^{-/+}$mutant mice (filled bars, $n=5$ mice, 15 cells) was not different from that observed in wild-type pyramidal cells (open bars, $n=$ 5 mice, 16 cells) at holding potentials of $-80 \mathrm{mV}$ (where the NMDA component is mostly blocked by extracellular $\mathrm{Mg}^{2+}$ ) and $+40 \mathrm{mV}$. The inset shows example EPSCs (average of 3 responses) recorded at -80 and $+40 \mathrm{mV}$ in cells from SynGAP ${ }^{-1+}$ and wild-type mice. Calibration: 50 pA, 25 msec. $b$, Peak current densities (picoamperes/picofarads) for currents evoked by application of $100 \mu \mathrm{M}$ NMDA $(+10 \mu \mathrm{M}$ glycine $)$ in the absence of extracellular $\mathrm{Mg}^{2+}$ in cultured neurons from SynGAP ${ }^{-1+}$ cells (black bar, $n=11)$, SynGAP ${ }^{-/-}$(gray bar, $\left.n=10\right)$, and wild-type mice (open bar, $n=11$ ). Currents were recorded at a holding potential of -70 $\mathrm{mV}$. $c$, Current-voltage relationships for NMDA receptor-mediated currents (normalized to maximal current) evoked by application of $100 \mu \mathrm{M}$ NMDA applied in the absence (right plot) and presence (left plot) of 1.0 mM extracellular $\mathrm{Mg}^{2+}$ in cultured neurons from wild-type (open symbols, $n=11$ cells), SynGAP ${ }^{-/+}$mice (black symbols, $n=11$ cells), and SynGAP ${ }^{-/-}$mice ( gray symbols, $n=10$ ). Calculated junction potential was $+15 \mathrm{mV}$ and is not corrected for in Figure $3 C$. Values correspond to mean \pm SEM.

stimulation delivered at $5 \mathrm{~Hz}$ induced only a small amount of potentiation in slices from wild-type mice (fEPSPs potentiated to $135 \pm 9 \%$ of baseline; $n=5$ ) and SynGAP ${ }^{-/+}$mice (fEPSPs were $117 \pm 5 \%$ of baseline; $n=9$; not significantly different from wild type; $p=0.07$ ). When delivered at higher frequencies (10 and 20 $\mathrm{Hz}$ ), 900 pulse trains of synaptic stimulation induced larger LTP in slices from wild-type mice (fEPSPs were potentiated to $153 \pm$ $5 \%, n=5$, and $141 \pm 4 \%$ of baseline, $n=7$, respectively). In contrast, these stimulation protocols had relatively little effect on synaptic transmission in slices from SynGAP ${ }^{-1+}$ mice (fEPSPs were potentiated to $116 \pm 2 \%, n=7$, after $10 \mathrm{~Hz}$ stimulation, $p<$ 0.001 compared with wild type, and were $123 \pm 7 \%$ of baseline, $n=7$, after $20 \mathrm{~Hz}$ stimulation, $p<0.05$ compared with wild type).

We also compared the induction of LTP in slices from Syn$\mathrm{GAP}^{-/+}$and wild-type mice in experiments in which trains of presynaptic stimulation were delivered at a fixed frequency $(5 \mathrm{~Hz})$ and the number of stimulation pulses in the train was varied (Fig. $5 d$ ). Trains of $5 \mathrm{~Hz}$ stimulation that consisted of just 25 pulses had little lasting effect on synaptic transmission in slices from wildtype and SynGAP ${ }^{-/+}$mice $[45 \mathrm{~min}$ after $5 \mathrm{~Hz}$ stimulation, fEPSPs were $115 \pm 5$ and $118 \pm 5 \%$ of baseline in slices from wild-type $(n=6)$ and SynGAP ${ }^{-1+}$ mice $(n=6)$, respectively]. Longer duration trains consisting of 75 and 150 pulses induced LTP in slices from wild-type mice [fEPSPs potentiated to $175 \pm$ $6 \%(n=5)$ and $194 \pm 14 \%(n=4)$ of baseline, respectively] but had little effect on synaptic transmission in slices from Syn$\mathrm{GAP}^{-/+}$mice [fEPSPs were $118 \pm 5 \%(n=6)$ and $117 \pm 3 \%$ $(n=4)$ of baseline; $p<0.01$ compared with wild type]. Similarly, a $5 \mathrm{~Hz}$ train of synaptic stimulation consisting of 300 pulses that induced an intermediate amount of LTP in slices from wild-type mice (fEPSPs potentiated to $143 \pm 7 \%$ of baseline; $n=5$ ) also induced significantly less LTP in slices from SynGAP ${ }^{-/+}$mice (fEPSPs were $106 \pm 2 \%$ of baseline; $n=6 ; p<0.01$ ). The postsynaptic responses evoked during all the trains of synaptic stimulation used to induce LTP in these experiments were similar in wild-type and SynGAP ${ }^{-/+}$slices (data not shown), suggesting that the LTP deficit observed in SynGAP ${ }^{-/+}$mice is not caused by alterations in presynaptic function.

To investigate whether changes in postsynaptic excitability and inhibitory synaptic transmission contribute to the reduction in LTP observed in SynGAP ${ }^{-/+}$mutant mice, we blocked inhibitory synaptic transmission by including picrotoxin $(100 \mu \mathrm{M})$ in the extracellular solution and examined the induction of LTP by pairing low-frequency $(5 \mathrm{~Hz})$ presynaptic fiber stimulation with depolarization of the postsynaptic cell produced by current injected through an intracellular recording electrode. Although this pairing protocol induced LTP in both wild-type and SynGAP ${ }^{-/+}$ cells, the average amount of potentiation induced in pyramidal cells from SynGAP ${ }^{-1+}$ mice was significantly less $(p<0.001)$ than that observed in cells from wild-type animals (Fig. 5e,f). This indicates that the LTP deficit observed in SynGAP ${ }^{-1+}$ mice is not caused by changes in inhibitory synaptic transmission or excitability of the postsynaptic CA1 pyramidal cells. In addition, because LTP was induced in these experiments by low-frequency synaptic stimulation paired with experimentally imposed postsynaptic depolarization, these findings indicate that the LTP deficit observed in SynGAP ${ }^{-/+}$mice is not caused by reduced postsynaptic depolarization resulting from presynaptic changes in synaptic transmission in SynGAP ${ }^{-/+}$slices that might alter transmitter release during LTP-inducing trains of synaptic stimulation. Together, these data indicate that SynGAP is part of a signaling pathway that facilitates LTP induction.

\section{SynGAP regulation of $\mathrm{H}-\mathrm{Ras}$ and ERK signaling}

Previous work suggests a number of possible mechanisms whereby reduced levels of SynGAP might lead to impaired LTP. Because SynGAP facilitates conversion of active, GTP-bound Ras to an inactive, GDP-bound form, one possibility is that the LTP deficits observed in slices from SynGAP ${ }^{-/+}$mice are caused 
a
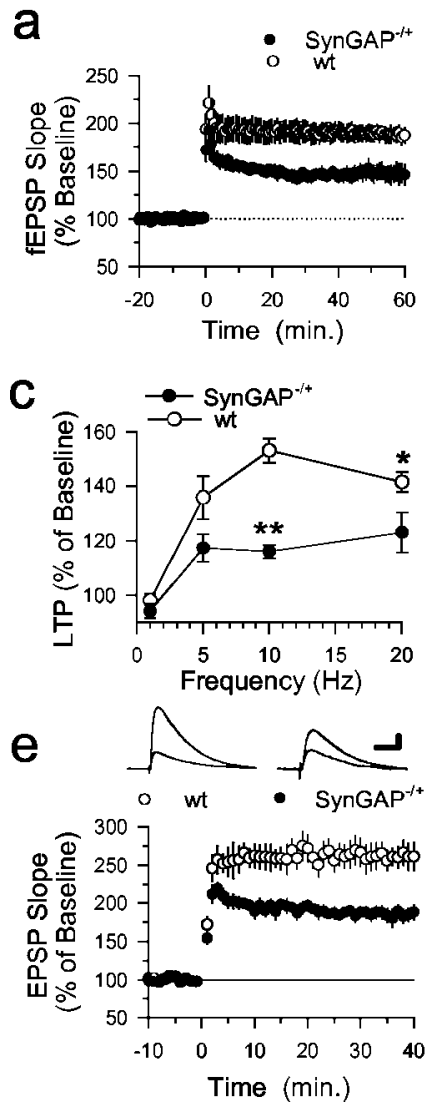

b
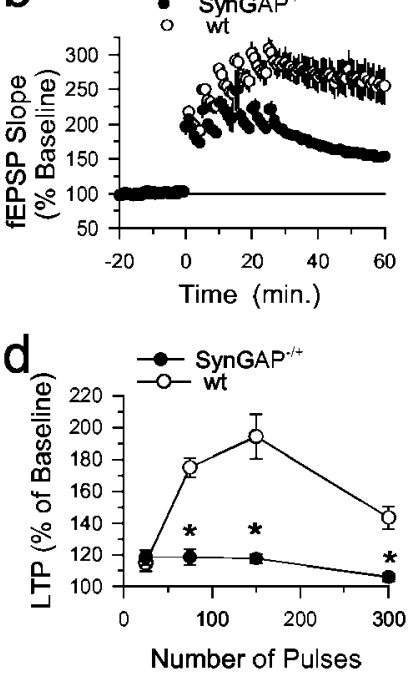

$f$

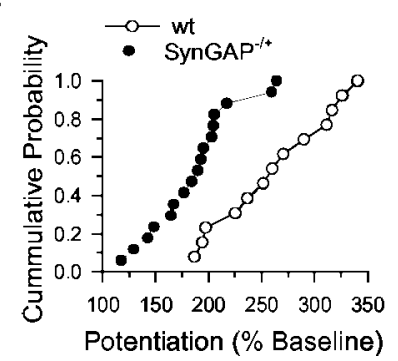

Figure 5. LTP is reduced in SynGAP ${ }^{-1+}$ mutants. $a$, After a $20 \mathrm{~min}$ period of baseline recording, two trains (1 sec duration) of $100 \mathrm{~Hz}$ stimulation were delivered with an intertrain interval of $10 \mathrm{sec}$ at time 0 . Although this protocol induced robust LTP in slices from wild-type animals $(\bigcirc$, fEPSPs potentiated to $188 \pm 9 \%$ of baseline, $n=11$ slices from 7 animals), it induced significantly less LTP in slices from Syn$\mathrm{GAP}^{-/+}$mutant mice $(\bullet$, fEPSPs potentiated to $150 \pm 10 \%$ of baseline, $n=11$ slices from 7 animals; $p<0.01$ compared with wild-type LTP). $b$, Six trains of $100 \mathrm{~Hz}$ stimulation (each $1 \mathrm{sec}$ in duration) were delivered with an intertrain interval of $5 \mathrm{~min}$ beginning at time $=0$ to induce saturating levels of LTP. In wild-type slices $(\bigcirc, n=7$ slices from 4 animals), fEPSPs were potentiated to $257 \pm 25 \%$ of baseline but potentiated to only $154 \pm 3 \%$ of baseline in slices from SynGAP ${ }^{-1+}$ mutant mice $(\bullet, n=11$ slices from 5 animals; $p<0.005$ compared with wild type). $c$, Summary graph showing the amount of LTP present $40-45 \mathrm{~min}$ after 900 pulse trains of $1,5,10$, or $20 \mathrm{~Hz}$ stimulation in slices from wild-type $(\bigcirc, n=5,5,5$, and 7 animals, respectively, for each frequency) and SynGAP ${ }^{-/+}$mutant mice $(\bullet, n=9,7,7$, and 7 animals, respectively, for each frequency). Although 1 and $5 \mathrm{~Hz}$ trains of synaptic stimulation had similar effects on synaptic transmission in slices from SynGAP ${ }^{-/+}$ and wild-type mice, 10 and $20 \mathrm{~Hz}$ trains of stimulation induced significantly less LTP in slices from SynGAP ${ }^{-/+}$mice $\left({ }^{* *} p<0.001,{ }^{*} p<0.05\right)$. $d$, Summary graph showing the amount of LTP present $40-45$ min after trains of $5 \mathrm{~Hz}$ stimulation containing $25,75,150$, and 300 stimulation pulses in slices from wild-type $(\bigcirc, n=5,5,4$, and 5 animals, respectively, for each point) and SynGAP ${ }^{-1+}$ mutants $(\bullet, n=6,6,4$, and 6 animals, respectively). Although a 25 pulse train of $5 \mathrm{~Hz}$ stimulation had similar effects on synaptic transmission in slices from wild-type and SynGAP ${ }^{-1+}$ mice, significantly less LTP was induced in SynGAP ${ }^{-/+}$slices by trains of $5 \mathrm{~Hz}$ stimulation containing 75,150 , and 300 pulses $\left({ }^{*} p<0.01\right)$. $e$, LTP induced by low-frequency $(5 \mathrm{~Hz})$ presynaptic fiber stimulation paired with postsynaptic depolarization is reduced in CA1 pyramidal cells from SynGAP ${ }^{-/+}$mice. EPSPs were paired with postsynaptic depolarization at time $=0$. EPSPs recorded between 25 and 30 min after pairing were potentiated to $262 \pm 15 \%$ of baseline in cells from wild-type slices $(\bigcirc, n=$ 13 cells from 7 animals) and to $185 \pm 9 \%$ of baseline in cells from SynGAP ${ }^{-1+}$ mice $(\bullet, n=12$ cells from 8 animals; $p<0.001$ compared with wild-type). The inset shows EPSPs (average of 3 responses) recorded

by increased levels of Ras activation. Indeed, a recent study reported that LTP is enhanced in H-Ras mutant mice, suggesting that H-Ras activation stimulates pathways that inhibit LTP induction (Manabe et al., 2000). Ras signaling may be an important component of the signaling pathway underlying NMDA receptormediated activation of ERK (Iida et al., 2001), and ERK activation is required for the induction of LTP by some patterns of synaptic stimulation (English and Sweatt, 1997; Impey et al., 1998; Coogan et al., 1999; Winder et al., 1999; Watabe et al., 2000; Sweatt, 2001). Thus, a second possibility is that a deficit in NMDAR-dependent activation of the MAPK pathway might be responsible for the LTP deficits observed in SynGAP ${ }^{-1+}$ mice.

To test these ideas, we first investigated whether basal levels of ERK pathway activity were altered in SynGAP ${ }^{-1+}$ mice by immunoblotting hippocampal extracts with antibodies to the phosphorylated active forms of MEK and ERK (Fig. 6a,b). Consistent with the hypothesis that SynGAP regulates the Ras-ERK pathway, basal levels of the phosphorylated, active form of MEK and ERK were increased in SynGAP ${ }^{-1+}$ extracts in the absence of a detectable change in total levels of both proteins. We next examined whether SynGAP also regulates NMDAR stimulationinduced activation of ERK pathway and whether the elevated basal levels might preclude further activation. Levels of phosphoERK2 (pERK2) were examined in extracts from hippocampal slices from wild-type and SynGAP ${ }^{-1+}$ mice that were either untreated or exposed to 2.5, 5, or $10 \mathrm{~min}$ applications of $100 \mu \mathrm{M}$ NMDA. As shown in Figure $6 b$, NMDA strongly activated ERK in slices from both wild-type and SynGAP ${ }^{-1+}$ mice. Although peak levels of pERK2 were higher at all three time points in extracts from SynGAP ${ }^{-/+}$mice, the magnitude of ERK activation relative to basal levels measured in untreated control slices was similar in slices from SynGAP ${ }^{-1+}$ and wild-type mice. Together these results indicate that although SynGAP may be a regulator of signaling through the Ras-ERK pathway, NMDA receptor activation still induces robust ERK activation in the hippocampus of SynGAP ${ }^{-/+}$mice.

To examine whether the reduced LTP observed in SynGAP ${ }^{-/+}$ mice might be caused by increased H-Ras activity, we compared

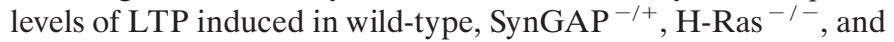
SynGAP ${ }^{-/+} / \mathrm{H}_{-\mathrm{Ras}^{-/-}}$mice by a short train of synaptic stimulation (150 pulses delivered at $5 \mathrm{~Hz})$ that induces robust, but nonsaturating, levels of LTP in wild-type slices. Although the induction of LTP by high-frequency synaptic stimulation is enhanced in H-Ras ${ }^{-1-}$ mice (Manabe et al., 2000), we found that a $5 \mathrm{~Hz}$ train of synaptic stimulation induced similar amounts of LTP in slices from H-Ras ${ }^{-1-}$ and wild-type mice (Fig. 6c). Compared with wild-type slices, however, a 150 pulse train of 5 $\mathrm{Hz}$ stimulation induced significantly less LTP in slices from SynGAP ${ }^{-/+}$mice $(p<0.02)$ (Fig. $\left.6 c\right)$. Moreover, the amount of LTP induced by 150 pulses of $5 \mathrm{~Hz}$ stimulation was also significantly reduced $(p<0.05)$ in slices from SynGAP ${ }^{-1+} / \mathrm{H}-\mathrm{Ras}^{-/-}$ double mutant mice compared with that seen in $\mathrm{H}-\mathrm{Ras}^{-1-} \mathrm{mu}-$ tant mice (Fig. 6c). On the basis of these findings, it seems unlikely that changes in H-Ras activity are responsible for the

during baseline and 30 min after pairing in cells from a wild-type animal (left set of traces) and SynGAP ${ }^{-1+}$ mutant animal (right set of traces). Calibration: $5 \mathrm{mV}, 25 \mathrm{msec}$. $f$, Cumulative probability distribution showing the amount of pairing-induced LTP seen in all cells represented by the average results shown in $e(\bigcirc$, cells from wild-type animals; $\bullet$, cells from SynGAP ${ }^{-/+}$mice). 

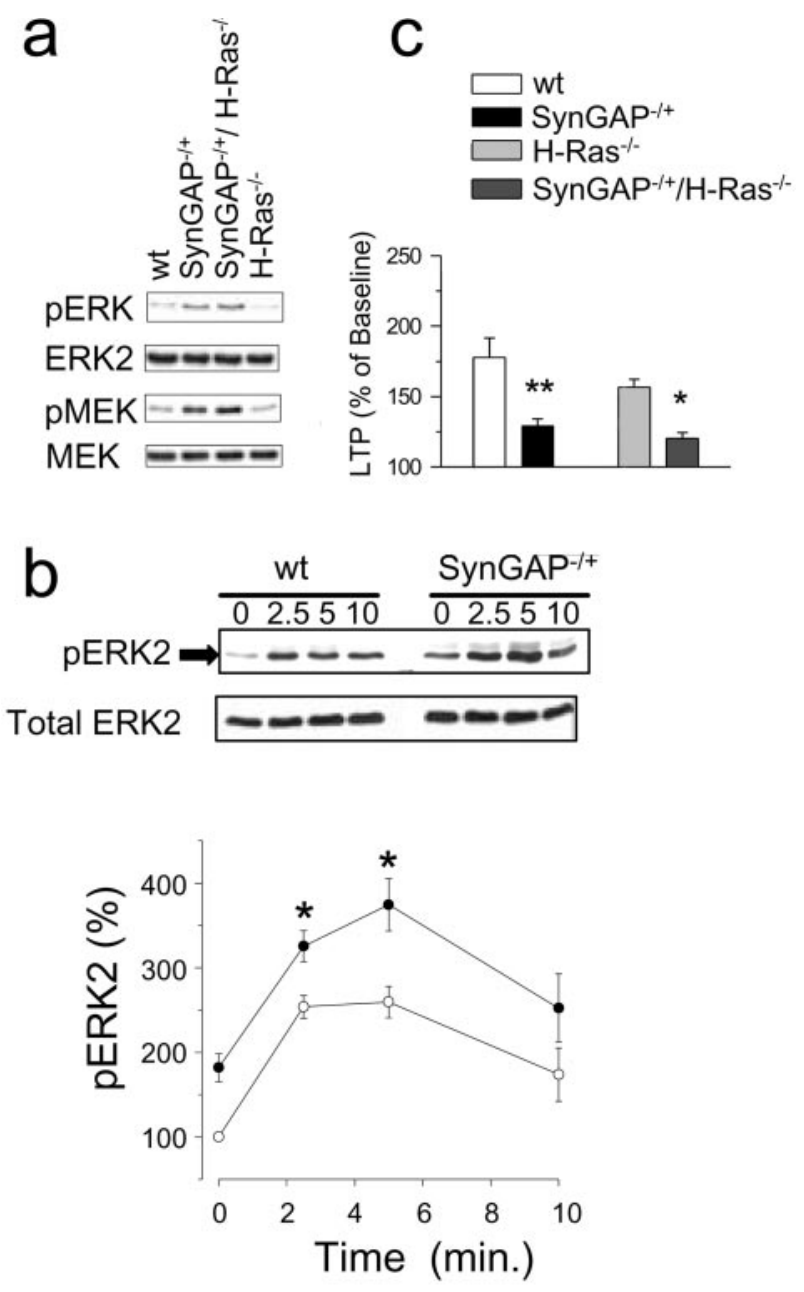

Figure 6. The role of H-Ras and SynGAP in LTP and ERK signaling. $a$, Basal levels of ERK pathway activation in SynGAP, H-Ras, and SynGAP/ Ras mutant hippocampus extracts. Immunoblots measuring MEK and ERK phosphorylation ( $p M E K, p E R K)$ and protein levels $(M E K, E R K)$ are shown for extracts from wild-type mice $(w t)$, SynGAP $^{-/+}$, SynGAP ${ }^{-/+} /$ $\mathrm{H}-\mathrm{Ras}^{-1-}$, and H-Ras ${ }^{-1-}$ mutants. Phosphorylated forms of MEK and ERK were increased in SynGAP ${ }^{-1+}$ and SynGAP ${ }^{-1+} / \mathrm{H}_{-} \mathrm{Ras}^{-1-}$ mutants. $b$, NMDA induced activation of ERK in hippocampal slices from wild-type and SynGAP ${ }^{-/+}$mice. Immunoblots show pERK levels in hippocampal slices from wild-type and SynGAP ${ }^{-/+}$mice that were either untreated (control) or exposed to $100 \mu \mathrm{M}$ NMDA $+10 \mu \mathrm{M}$ glycine for $2.5,5$, or 10 min. The top blot shows the levels of pERK2 (arrowhead) and pERK1 (top faint band). The bottom blot shows the total protein level of ERK2. The graph shows the change in ERK2 activation as measured using pERK antibody. For each experiment, pERK2 levels were normalized relative to ERK2 and control slices from wild type and then quantified using image analysis software (NIH Image version 1.62) and represented graphically. Mean and SEM are indicated, and significant difference after stimulation is shown $\left({ }^{*} p<0.05\right)$. Note that although basal levels of pERK2 are clearly elevated in SynGAP ${ }^{-1+}$ slices, NMDA induces further increases in pERK. $\bigcirc$, Wild type; $\bullet$, SynGAP ${ }^{+/-} . c$, Summary of the amount of potentiation seen $45 \mathrm{~min}$ after a 150 pulse train of $5 \mathrm{~Hz}$ stimulation in wild-type, SynGAP ${ }^{-/+},{\mathrm{H}-\mathrm{Ras}^{-/-}}^{-}$, and SynGAP ${ }^{-/+} / \mathrm{H}_{-} \mathrm{Ras}^{-1-}$ double mutants. After $5 \mathrm{~Hz}$ stimulation, synaptic transmission potentiated to $178 \pm 14 \%$ of baseline in slices from wild-type animals ( $n=12$ slices from 6 animals) but to only $129 \pm 5 \%$ of baseline in slices from SynGAP ${ }^{-/+}$mice $(n=10$ slices from 5 animals; $* * p<0.02$ compared with wild type). The amount of LTP induced by this protocol was also reduced significantly in $\mathrm{SynGAP}^{-1+} / \mathrm{H}-$ Ras $^{-1-}$ double mutants (fEPSPs were $120 \pm 4 \%$ of baseline; $n=9$ slices from 5 animals; ${ }^{*} p<0.05$ ) compared with that seen in H-Ras ${ }^{-1-}$ mutant mice (fEPSPs potentiated to $157 \pm 13 \%$ of baseline; $n=12$ slices from 6 animals).
LTP deficits observed in SynGAP ${ }^{-/+}$mice. This conclusion is further supported by our finding that NMDAR-mediated synaptic currents and responses in slices and cultured neurons from SynGAP ${ }^{-/+}$mice were not different from wild type (Fig. 4), whereas NMDAR-mediated responses in $\mathrm{H}-\mathrm{Ras}^{-1-}$ mutant mice are strongly upregulated (Manabe et al., 2000).

In these experiments we also tested whether H-Ras was required for SynGAP regulation of basal levels of ERK pathway activation by immunoblotting extracts from $\mathrm{H}-\mathrm{Ras}^{-/-}$and Syn$\mathrm{GAP}^{-/+} / \mathrm{H}-\mathrm{Ras}^{-/-}$double mutant mice. As shown in Figure $6 a$, levels of MEK and ERK phosphorylation in $\mathrm{H}-\mathrm{Ras}^{-1-}$ mice were similar to wild type and increased in $\operatorname{SynGAP}^{-/+} / \mathrm{H}-$ $\mathrm{Ras}^{-1-}$ double mutant mice to levels similar to that observed in SynGAP ${ }^{-1+}$ mutants. These results indicate that signaling through H-Ras is not required for elevated basal levels of ERK activation in SynGAP ${ }^{-/+}$mutants.

\section{Genetic dissection of SynGAP and PSD-95 pathways}

In addition to investigating the role of H-Ras as a potential component of the downstream pathways underlying the role of SynGAP in LTP, we also used a genetic approach to examine the relationship between SynGAP and its potential upstream partner PSD-95. Because SynGAP and PSD-95 are both required for NMDAR-dependent plasticity, we can use genetic tools to determine their relationship within pathways. One possibility is a signaling pathway that leads from NMDAR to PSD-95 to SynGAP. A second possibility is that SynGAP is not downstream of PSD-95, as in the first scenario, but instead is in a separate parallel pathway downstream of the NMDAR. A genetic test that can distinguish these possibilities is to examine LTP in Syn-

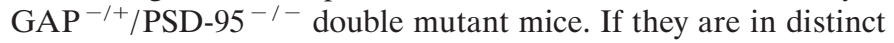
parallel pathways, then the predicted magnitude of LTP will be intermediate between the enhanced LTP in PSD-95 ${ }^{-1-}$ and reduced LTP in SynGAP ${ }^{-/+}$mutants. Alternatively, if PSD-95 is upstream of SynGAP, then the magnitude of LTP in the double mutant may resemble that seen in PSD-95 ${ }^{-/-}$mutants. As shown in Figure 7, the amount of potentiation induced by a 150 pulse train of $5 \mathrm{~Hz}$ stimulation in slices from SynGAP ${ }^{-/+} / \mathrm{PSD}_{-} 95^{-/-}$ mutants was identical to that seen in PSD-95 ${ }^{-/-}$mice, supporting the model that there is a signaling pathway from NMDA to PSD-95 to SynGAP. We also found that a 900 pulse train of $5 \mathrm{~Hz}$ stimulation, which induces little or no LTP in slices from wildtype mice (Thomas et al., 1996) and large (more than twofold) LTP in PSD-95 mutant slices (Migaud et al., 1998), also induced large LTP (more than twofold) in slices from SynGAP ${ }^{-/+} /$PSD$95^{-/-}$mutant mice (data not shown). Thus, the LTP phenotype in SynGAP ${ }^{-1+} /$ PSD $-95^{-/-}$double mutants is consistent with previously reported hypotheses suggesting a pathway from NMDARs to SynGAP via PSD-95 (Chen et al., 1998; Kim et al., 1998).

\section{SynGAP regulates rate of learning}

PSD-95 ${ }^{-1-}$ mutants show a severe impairment in the performance of a spatial learning task (Migaud et al., 1998), suggesting that PSD-95-dependent signaling pathways have a crucial role in spatial learning. Thus, to assess the potential role of SynGAP in the PSD-95-associated signaling pathways involved in learning, we examine spatial learning in SynGAP ${ }^{-1+}$ mutant mice. To afford a comparison, we deliberately chose a water maze training protocol that was identical to that used in the study of PSD-95 mutant mice. Both wild-type $(n=21)$ and heterozygous Syn$\mathrm{GAP}^{-/+}$mutants $(n=21)$ were trained in cued and spatial 
- wild type

- SynGAP ${ }^{-1+}$

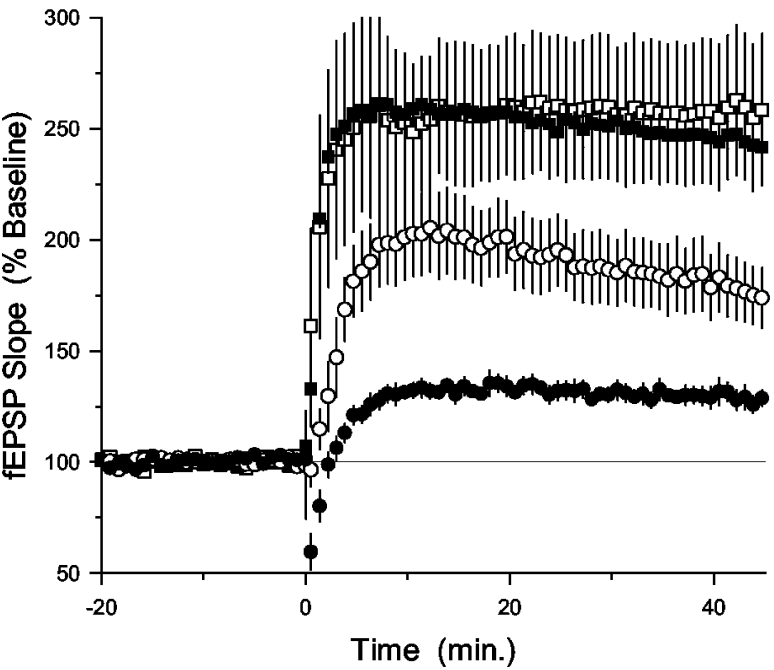

Figure 7. LTP in single and double mutants of SynGAP and PSD-95. A brief train of $5 \mathrm{~Hz}$ stimulation (150 pulses, delivered at time $=0)$ induces robust LTP in wild-type slices $(\bigcirc, n=12$ slices from 6 animals) but induces only a small potentiation in slices from $\operatorname{SynGAP}^{-/+}$mice $(\mathbf{O}, n=$ 10 slices from 5 animals) (data from the same experiments summarized in Fig. 5c). In slices from both PSD-95 $-1-$ and SynGAP ${ }^{-/+} /$PSD $^{-95^{-/-}}$ double mutant mice, 150 pulse trains of $5 \mathrm{~Hz}$ stimulation induce large LTP. Forty-five minutes after $5 \mathrm{~Hz}$ stimulation (delivered at time $=0$ ), synaptic transmission was potentiated to $258 \pm 33 \%$ of baseline in PSD-95 $-1-$ slices $(\square, n=6$ slices from 4 animals $)$ and was potentiated to

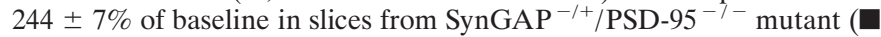
$n=9$ slices from 4 animals).

versions of the water maze, with the experimenter blind to genotype throughout.

In the NMDA receptor-independent cue task, both wild-type and SynGAP ${ }^{-/+}$mutant mice learned to approach a randomly located platform marked by a visible cue with an equivalent ( $F$ $<1$ ) and progressive reduction in path length over successive trials (Fig. $8 a$ ). In the NMDA receptor-dependent spatial task, both groups showed a decrease in path length over the course of 20 trials (mutants: $F_{(19,380)}=1.91 ; p<0.05$; wild types: $F_{(19,380)}$ $=2.74 ; p<0.001)$, with the swim paths of SynGAP ${ }^{-/+}$mutants being slightly longer overall than those of wild types $\left(F_{(1,40)}=\right.$ $6.75 ; p<0.05)$. All mice were then subject to the first transfer test (platform removed). On the conventional measure of time in the training quadrant, which revealed a striking impairment in PSD$95^{-1-}$ mutants (Migaud et al., 1998, their Fig. 7d), the difference between SynGAP ${ }^{-1+}$ mutants and wild types approached but did not reach significance $\left(t_{(40)}=1.98 ; 0.10>p>0.05\right)$. However, using the more sensitive measure of the proportion of time spent in a zone centered around the target platform relative to time in all four possible platform locations (Moser et al., 1993), the SynGAP ${ }^{-1+}$ mutants showed significantly less focused swimming (Fig. $8 c)\left(t_{(40)}=3.08 ; p<0.005\right)$. When PSD-95 ${ }^{-/-}$mutants were given overtraining on the spatial task to reach a strict performance criterion, only 2 of 12 mutant mice were successful compared with 9 of 9 wild types (Migaud et al., 1998) $\left(\chi^{2}=14.3\right.$; $p<0.001$ ). In contrast, 11 of 21 SynGAP $^{-/+}$mice (compared with 20 of 21 wild types) reached this criterion. Although worse than wild types $\left(\chi^{2}=9.98 ; p<0.005\right)$, significantly more Syn$\mathrm{GAP}^{-1+}$ mice reached criterion than PSD-95 ${ }^{-1-}$ mice $\left(\chi^{2}=\right.$
5.22; $p<0.05)$. Consistent with this result, when tested in the second transfer test immediately after reaching criterion, Syn$\mathrm{GAP}^{-/+}$mice showed moderately focused searching in the target zone (Fig. $8 c$ ). This result contrasts with the performance of PSD-95 $-1-$ mutants, who remained at chance in both transfer tests (Fig. 8e). Comparison of the two mutant strains revealed that SynGAP ${ }^{-/+}$mice were significantly less impaired than PSD$95^{-/-}$mice $\left(F_{(1,31)}=5.31 ; p<0.05\right)$, and a group $\times$ transfer test interaction was obtained $\left(F_{(1,31)}=5.10 ; p<0.05\right)$ : SynGAP ${ }^{-/+}$ and PSD-95 ${ }^{-1-}$ mice performed equally badly on transfer test 1 , but SynGAP mice performed significantly better than PSD$95^{-1-}$ mice on transfer test $2(p<0.05)$.

Thus, as also displayed qualitatively in the representative swim paths (Fig. $8 d$ ), SynGAP ${ }^{-/+}$mice showed a slower rate of spatial learning characterized by more diffuse searching early in training (transfer test 1), but they were able to locate the platform after further training (transfer test 2); PSD-95 ${ }^{-1-}$ mice searched aberrantly throughout all phases of spatial training (Fig. 8e,f) [reanalysis of data from Migaud et al., (1998)]. A framework for thinking about these mutants is shown in Fig. $8 g$, in which Syn$\mathrm{GAP}^{-/+}$mutants gradually approach an equivalent asymptote of learning to that reached by control animals, whereas PSD-95 ${ }^{-/-}$ mice do not.

In contrast to their reduced rate of learning, the subset of SynGAP ${ }^{-/+}$mutants tested $(n=12)$ showed a normal rate of forgetting relative to wild types $(n=12)$. Time spent in the target zone (see Materials and Methods) was similar in both groups on transfer test 3 ( $7 \mathrm{~d}$ retention test; mutants: $52.10 \pm 8.15 \%$; wild types: $60.66 \pm 7.43 \%)$ and transfer test 4 (45 d retention test; mutants: $35.34 \pm 5.21 \%$; wild types: $36.70 \pm 4.21 \%$ ). An ANOVA of performance on transfer tests 2,3 , and 4 (i.e., both immediate and long-term retention tests) revealed no overall group difference between mutants and wild types $(F<1)$, and no group $\times$ transfer test interaction $(F<1)$, indicating that SynGAP ${ }^{-/+}$ mutants, although initially slower to learn, have unimpaired longterm memory. As expected, significant forgetting was observed over time $\left(F_{(2,44)}=12.46 ; p<0.001\right)$, but performance remained above chance even in the $45 \mathrm{~d}$ retention test $\left(t_{(23)}=3.36 ; p<\right.$ $0.005)$. This finding is consistent with the notion that SynGAP contributes to the induction machinery for memory encoding but not to the persistence of memory traces over time.

\section{DISCUSSION}

\section{SynGAP and PSD-95 regulate NMDA receptor signaling pathways}

Many of the signaling proteins required for LTP induction are found in complexes associated with the NMDA receptor (Husi et al., 2000). Although it is thought that signaling complexes might provide a microenvironment for local signaling, the significance of the complex of NMDA receptor with PSD-95 and other proteins is not well understood in the context of synaptic plasticity and learning. The fact that the NMDA receptor is directly attached to PSD-95, which in turn is directly attached to SynGAP, allows us to contrast the phenotypes of mice carrying mutations in these genes and thereby explore how these complexes participate in the induction of plasticity.

We found that excitatory synapses in SynGAP ${ }^{-/+}$mutants and wild-type mice showed similar responses to patterns of synaptic activation that were below threshold for LTP induction $(<5 \mathrm{~Hz})$. However, significantly less potentiation was induced in Syn$\mathrm{GAP}^{-/+}$mutant slices by all patterns of synaptic stimulation that exceeded the threshold for LTP induction in wild-type slices. 

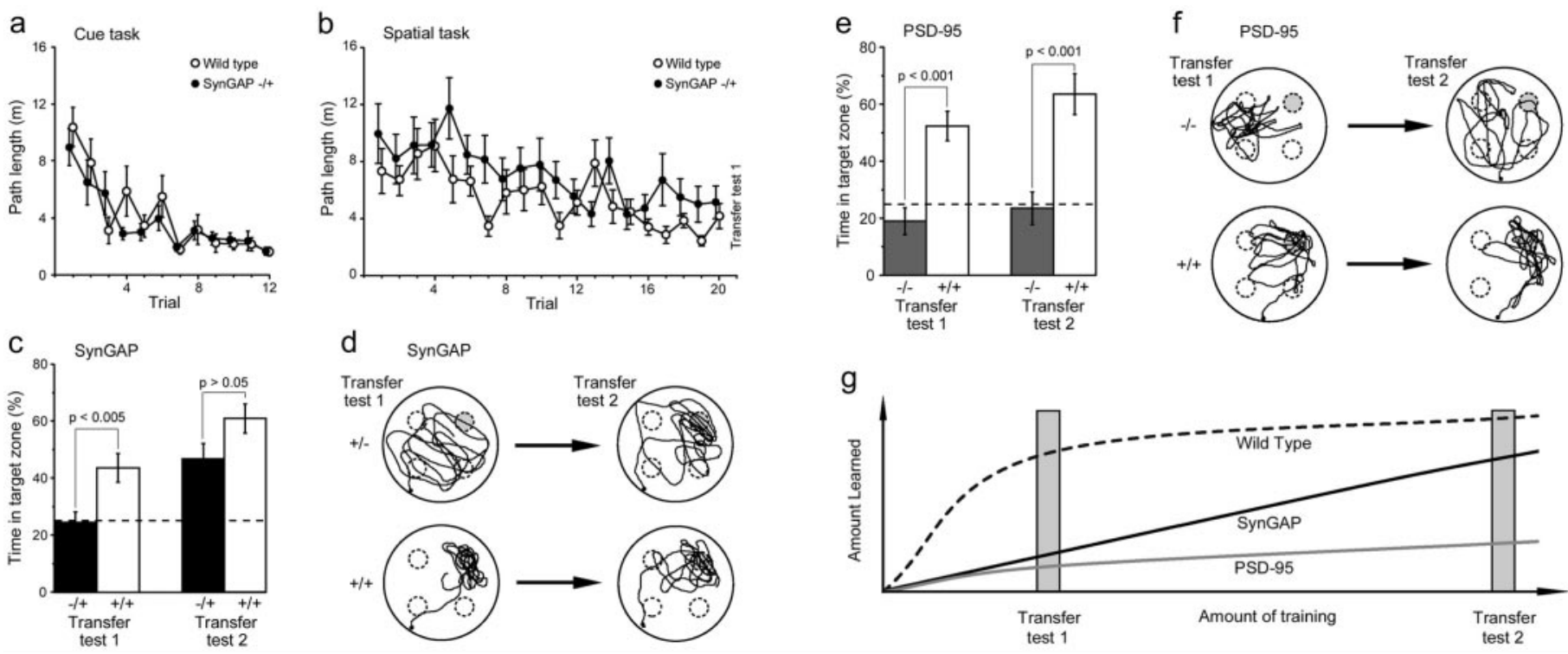

Figure 8. Learning and memory in SynGAP mutant mice. $a$, Path length (mean \pm SEM) across 3 d of training to a visible cue (4 trials per day) in SynGAP ${ }^{-1+}(n=21)$ and wild-type $(n=21)$ mice. Both groups performed equally well. $b$, Path length across $5 \mathrm{~d}$ of spatial training to a hidden platform. SynGAP mutants were slightly impaired relative to wild types. $c$, Time spent in the target zone on transfer tests 1 and 2 , expressed as a percentage of the total time spent in all four zones. On transfer test 1, SynGAP mutants were significantly impaired relative to wild types, but after training to a performance criterion, mutants searched almost as accurately as wild types on transfer test 2 . $d$, Representative swim paths of individual SynGAP ${ }^{-/+}$ and wild-type mice on transfer tests 1 and 2. Dashed circles indicate the four zones, with the target zone filled in gray. Platform locations were counterbalanced, but swim paths have been rotated for display purposes such that the target zone always appears in the northeast quadrant of the pool. The wild-type mouse searched in the correct location in both transfer tests, whereas the mutant performed at chance on transfer test 1 but searched almost as accurately as the wild type on transfer test 2 . $e$, Time spent in the target zone on transfer tests 1 and 2 for PSD-95 ${ }^{-/-}$mutants $(n=12)$ and wild types $(n=9)$. Wild types performed well in both transfer tests, but PSD ${ }^{-1}$ - mutants performed at chance throughout. $f$, Representative swim paths of a PSD-95 $5^{-1-}$ mutant and a wild-type mouse. Note that the mutant fails to search in the target location even after extensive training (Transfer test 2). $g$, A possible framework for interpreting the transfer test data. Wild-type mice learn rapidly, soon reaching an asymptote. SynGAP mutants learn slowly, but gradually begin to approach an asymptote equivalent to that reached by wild types. PSD-95 mutants, in contrast, learn little, regardless of the amount of training that they receive.

This LTP deficit in SynGAP ${ }^{-/+}$mice occurs in the absence of any obvious changes in basal synaptic transmission and NMDA receptor function, and it is present under experimental conditions where potential changes in inhibitory synaptic transmission and postsynaptic excitability should have little effect on LTP induction. Together, these results suggest that SynGAP has an important role in coupling NMDA receptor activation to downstream signaling pathways involved in LTP. In contrast, PSD-95 mutants exhibit enhanced LTP across a wide range of frequencies of synaptic stimulation, suggesting that PSD-95 may normally couple NMDA receptors to signaling pathways that inhibit or restrain LTP induction (Migaud et al., 1998). One simple model consistent with these findings is that PSD-95 couples NMDA receptors to signaling pathways with both inhibitory and facilitatory roles in LTP induction. Indeed, PSD-95 contains multiple protein interaction domains (Kennedy, 1998; Sheng 2001) that can couple NMDARs to distinct downstream signaling pathways. Although our observations suggest that SynGAP is part of an LTP facilitating pathway and our analysis of LTP in SynGAP ${ }^{-/+} /$PSD$95^{-1-}$ double mutants is consistent with a model in which SynGAP is functionally downstream of PSD-95, the molecular components of pathways regulated by PSD-95 that might be involved in suppressing LTP induction remain unknown.

\section{SynGAP and ERK signaling}

Previous studies have suggested that SynGAP may act to couple increases in intracellular calcium to activation of the Ras/ERK pathway (Chen et al., 1998; Kim et al., 1998), a pathway known to have an important role in both LTP and learning (for review, see
Impey et al., 1999; Sweatt, 2001). In a general sense, the phenotype of SynGAP ${ }^{-/+}$mice is consistent with this model in several ways, i.e., SynGAP ${ }^{-1+}$ mutants exhibit alterations in basal levels of activated ERK as well as deficits in both synaptic plasticity and learning. Several of our findings, however, are more difficult to reconcile with the specific hypothesis that SynGAP is required for NMDA receptor-dependent activation of the ERK pathway and that the LTP deficit seen in slices from SynGAP ${ }^{-/+}$mice arises from alterations in ERK signaling. For instance, several studies have found that pharmacological inhibition of MEK suppresses LTP (English and Sweatt, 1997; Impey et al., 1998; Coogan et al., 1999; Winder et al., 1999; Watabe et al., 2000) and that increases in ERK activation after activation of G-protein-coupled receptors facilitate LTP induction (Winder et al., 1999; Watabe et al., 2000). Although these findings indicate that ERK activation is required for or facilitates LTP induction, or both, increased basal levels of activated MEK and ERK in SynGAP mutants are associated with reduced LTP. What might be responsible for this apparent dissociation? One possibility is that constitutive elevation of ERK activity increases the "threshold" for LTP induction, as is the case in transgenic mice expressing constitutively active kinases (Mayford et al., 1995; Lu et al., 1999). This seems unlikely, however, because we observed LTP deficits in SynGAP ${ }^{-/+}$ slices across a wide range of LTP induction protocols. Another possibility is that the constitutive elevation of ERK activity seen in SynGAP ${ }^{-/+}$mice potentiates synapses and thus partially occludes stimulation-induced LTP in SynGAP ${ }^{-/+}$slices. This also seems unlikely because previous studies have found that ERK 
activation is not sufficient for LTP induction (Winder et al., 1999; Dudek and Fields, 2001). Moreover, neither the maximal fEPSP amplitude generated in slices from SynGAP ${ }^{-/+}$mice nor the fiber volley to fEPSP slope ratios measured using a range of different stimulation intensities was altered in SynGAP ${ }^{-/+}$slices as would be expected if synapses were in a "prepotentiated" state in slices from SynGAP ${ }^{-/+}$mice. We also found that pharmacological activation of NMDA receptors induces robust ERK activation in slices from SynGAP ${ }^{-1+}$ mice, suggesting that LTP is not compromised in SynGAP ${ }^{-/+}$mutants because of an inability of the NMDA receptor to activate ERK. Finally, we found that SynGAP $^{-/+}$mice exhibit LTP deficits after both $100 \mathrm{~Hz}$ stimulation and low-frequency synaptic stimulation paired with postsynaptic depolarization, stimulation protocols that under our experimental conditions induce an ERK-independent form of LTP in wild-type slices (Winder et al., 1999; Watabe et al., 2000). Although none of these observations alone formally rules out the possibility that a subtle deficit in NMDA receptor-dependent activation of ERK might contribute to the reduced LTP seen in SynGAP ${ }^{-1+}$ mice, together they suggest that the LTP deficit in SynGAP ${ }^{-/+}$mice involves changes in signaling pathways downstream of SynGAP other than (or in addition to) ERK. One possibility is that SynGAP may regulate signaling through a Ras/PI3 kinase pathway that may have an important role in LTP (Kelly and Lynch, 2000; Sanna et al., 2002).

Although the molecular details of the downstream components of the SynGAP-dependent signaling pathway involved in LTP remain to be fully determined, our characterization of LTP in $\mathrm{H}_{-\mathrm{Ras}^{-1-}}$ and $\mathrm{H}-\mathrm{Ras}^{-/-} / \mathrm{SynGAP}^{-1+}$ mice indicates that $\mathrm{H}-\mathrm{Ras}$ is not required for the changes in LTP and basal levels of $\mathrm{MEK} /$ ERK activation seen in SynGAP ${ }^{-/+}$mice. This suggests that other members of the Ras family that are expressed in the hippocampus (Fang et al., 2000; Manabe et al., 2000) (Fig. 1d) have an important role in the SynGAP-dependent signaling pathways involved in LTP induction. Interestingly, although the induction of LTP by high-frequency stimulation $(100 \mathrm{~Hz})$ is enhanced in H-Ras mutant mice (Manabe et al., 2000), we found that low-frequency $(5 \mathrm{~Hz})$ stimulation-induced LTP is normal in these mice. This suggests that the involvement of H-Rasdependent signaling pathways in LTP may be highly dependent on the pattern of synaptic stimulation used to induce LTP, a phenomenon reminiscent of the role of protein kinase A in LTP of excitatory synapses in the hippocampal CA1 region (Blitzer et al., 1995; Thomas et al., 1996; Abel et al., 1997).

\section{Learning and plasticity}

Both SynGAP and PSD-95 mutant mice exhibit spatial learning deficits. However, SynGAP mutant mice show reduced LTP with an effect on the rate of spatial learning, whereas the PSD-95 mutants show enhanced LTP with severely impaired spatial learning. Thus, genetic manipulations that interfere with two interacting proteins bound to the NMDA receptor appear to dissociate a simple correlation between LTP and learning. On the one hand, this raises the possibility that some pathways within NRCs play a more significant role in plasticity, whereas others are involved primarily in learning (Grant, 1999). On the other hand, it is equally likely that signaling within NRCs may control other features of synaptic plasticity and metaplasticity that are more relevant to spatial learning than the overall magnitude of LTP. For instance, signaling events controlled by the complex may have an important role in generating the synaptic "rules" (such as frequency sensitivity, EPSP/spike timing, etc.) that govern how specific patterns of synaptic activity are converted into persistent changes in synaptic strength. Changes in these parameters may be more relevant to how well information is stored during learning.

Although much remains to be uncovered regarding how the composition of NRC coordinates postsynaptic signaling pathways involved in plasticity and learning, our results support the notion that protein interactions involving NMDA receptors, PSD-95, and SynGAP have a crucial role in both LTP and spatial learning. Given that genetic and pharmacological perturbations of a number of NRC proteins also result in learning impairments (Husi et al., 2000), a better understanding of signal integration by NRCs is likely to reveal important details regarding how these complexes orchestrate various aspects of the cell biology responsible for the neuronal changes underlying learning and other forms of plasticity.

\section{REFERENCES}

Abel T, Nguyen PV, Barad M, Deuel TA, Kandel ER, Bourtchouladze R (1997) Genetic demonstration of a role for PKA in the late phase of LTP and in hippocampus-based long-term memory. Cell 88:615-626.

Blackstone C, Sheng M (1999) Protein targeting and calcium signaling microdomains in neuronal cells. Cell Calcium 26:181-192.

Blitzer RD, Wong T, Nouranifar R, Iyengar R, Landau EM (1995) Postsynaptic cAMP pathway gates early LTP in hippocampal CA1 region. Neuron 15:1403-1414.

Bolam JP (1992) Preparation of central nervous system tissue for light and electron microscopy. In: Experimental neuroanatomy: a practical approach (Rickwood D, Hames BD, eds), pp 1-29. New York: Oxford UP.

Chen HJ, Rojas-Soto M, Oguni A, Kennedy MB (1998) A synaptic Ras-GTPase activating protein (p135 SynGAP) inhibited by CaM kinase II. Neuron 20:895-904.

Coogan AN, O'Leary DM, O'Connor JJ (1999) P42/44 MAP kinase inhibitor PD98059 attenuates multiple forms of synaptic plasticity in rat dentate gyrus in vitro. J Neurophysiol 81:103-110.

Dudek SM, Fields RD (2001) Mitogen-activated protein kinase/extracellular signal-regulated kinase activation in somatodendritic compartments: roles of action potentials, frequency, and mode of calcium entry. J Neurosci 21:RC122(1-5).

English JD, Sweatt JD (1997) A requirement for the mitogen-activated protein kinase cascade in hippocampal long term potentiation. J Biol Chem 272:19103-19106

Erzurumlu RS, Kind PC (2001) Neural activity: sculptor of "barrels" in the neocortex. Trends Neurosci 24:589-595.

Fang M, Jaffrey SR, Sawa A, Ye K, Luo X, Snyder SH (2000) Dexras1: a $G$ protein specifically coupled to neuronal nitric oxide synthase via CAPON. Neuron 28:183-193.

Friedrich G, Soriano P (1991) Promoter traps in embryonic stem cells: a genetic screen to identify and mutate developmental genes in mice. Genes Dev 5:1513-1523.

Garner CC, Nash J, Huganir RL (2000) PDZ domains in synapse assembly and signaling. Trends Cell Biol 10:274-280.

Gille H, Downward J (1999) Multiple ras effector pathways contribute to G(1) cell cycle progression. J Biol Chem 274:22033-22040.

Grant SG (1999) Genetic dissection of a postsynaptic multiprotein complex controlling synaptic plasticity and learning in the mouse. In: Handbook of molecular-genetic techniques for brain and behavior research (Crusio WE, Gerlai RT, eds), pp 315-329. New York: Elsevier.

Hardingham GE, Arnold FJ, Bading H (2001) A calcium microdomain near NMDA receptors: on switch for ERK-dependent synapse-tonucleus communication. Nat Neurosci 4:565-566.

Husi H, Ward MA, Choudhary JS, Blackstock WP, Grant SG (2000) Proteomic analysis of NMDA receptor-adhesion protein signaling complexes. Nat Neurosci 3:661-669.

Iida N, Namikawa K, Kiyama H, Ueno H, Nakamura S, Hattori S (2001) Requirement of Ras for the activation of mitogen-activated protein kinase by calcium influx, cAMP, and neurotrophin in hippocampal neurons. J Neurosci 21:6459-6566.

Impey S, Obrietan K, Wong ST, Poser S, Yano S, Wayman G, Deloulme JC, Chan G, Storm DR (1998) Cross talk between ERK and PKA is required for $\mathrm{Ca}^{2+}$ stimulation of CREB-dependent transcription and ERK nuclear translocation. Neuron 21:869-883.

Impey S, Obrietan K, Storm DR (1999) Making new connections: role of ERK/MAP kinase signaling in neuronal plasticity. Neuron 23:11-14.

Kelly A, Lynch MA (2000) Long-term potentiation in dentate gyrus of the rat is inhibited by the phosphoinositide 3-kinase inhibitor, wortmannin. Neuropharmacology 39:643-651. 
Kennedy MB (1998) Signal transduction molecules at the glutamatergic postsynaptic membrane. Brain Res Brain Res Rev 26:243-257.

Kim JH, Liao D, Lau LF, Huganir RL (1998) SynGAP: a synaptic RasGAP that associates with the PSD-95/SAP90 protein family. Neuron 20:683-691.

Kornau HC, Schenker LT, Kennedy MB, Seeburg PH (1995) Domain interaction between NMDA receptor subunits and the postsynaptic density protein PSD-95. Science 269:1737-1740.

Lu YF, Kojima N, Tomizawa K, Moriwaki A, Matsushita M, Obata K, Matsui H (1999) Enhanced synaptic transmission and reduced threshold for LTP induction in fyn-transgenic mice. Eur J Neurosci 11:75-82.

Manabe T, Aiba A, Yamada A, Ichise T, Sakagami H, Kondo H, Katsuki M (2000) Regulation of long-term potentiation by H-Ras through NMDA receptor phosphorylation. J Neurosci 20:2504-2511.

Mayford M, Wang J, Kandel ER, O'Dell TJ (1995) CaMKII regulates the frequency-response function of hippocampal synapses for the production of both LTD and LTP. Cell 81:891-904.

Migaud M, Charlesworth P, Dempster M, Webster LC, Watabe AM, Makhinson M, He Y, Ramsay MF, Morris RG, Morrison RJ, O'Dell TJ, Grant SGN (1998) Enhanced long-term potentiation and impaired learning in mice with mutant postsynaptic density-95 protein. Nature 396:433-439.

Morrison BM, Janssen WG, Gordon JW, Morrison JH (1998) Light and electron microscopic distribution of the AMPA receptor subunit, GluR2, in the spinal cord of control and G86R mutant superoxide dismutase transgenic mice. J Comp Neurol 395: 523-534.

Moser E, Moser MB, Andersen P (1993) Spatial learning impairment parallels the magnitude of dorsal hippocampal lesions, but is hardly present following ventral lesions. J Neurosci 13:3916-3925.

Papaioannou V, Johnson R (2000) Production of chimeras by blastocyst and morula injection of targeted ES cells. In: Gene targeting: a Practical approach, Ed 2 (Joyner AL, ed), pp 133-175. New York: Oxford UP.

Sanna PP, Cammalleri M, Berton F, Simpson C, Lutjens R, Bloom FE, Francesconi W (2002) Phosphatidylinositol 3-kinase is required for the expression but not the induction or maintenance of long-term potentiation in the hippocampal CA1 region. J Neurosci 22:3359-3365.

Sheng M (2001) Molecular organization of the postsynaptic specialization. Proc Natl Acad Sci USA 98:7058-7061.

Sweatt JD (2001) The neuronal MAP kinase cascade: a biochemical signal integration system subserving synaptic plasticity and memory. J Neurochem 76:1-10.

Thomas MJ, Moody TD, Makhinson M, O'Dell TJ (1996) Activitydependent beta-adrenergic modulation of low frequency stimulation induced LTP in the hippocampal CA1 region. Neuron 17:475-482.

Watabe AM, Zaki PA, O'Dell TJ (2000) Coactivation of betaadrenergic and cholinergic receptors enhances the induction of longterm potentiation and synergistically activates mitogen-activated protein kinase in the hippocampal CA1 region. J Neurosci 20:5924-5931.

Westphal RS, Tavalin SJ, Lin JW, Alto NM, Fraser ID, Langeberg LK, Sheng M, Scott JD (1999) Regulation of NMDA receptors by an associated phosphatase-kinase signaling complex. Science 285:93-96.

Winder DG, Martin KC, Muzzio IA, Rohrer D, Chruscinski A, Kobilka B, Kandel ER (1999) ERK plays a regulatory role in induction of LTP by theta frequency stimulation and its modulation by $\beta$-adrenergic receptors. Neuron 24:715-726. 